\title{
Eutrophication of Chesapeake Bay: historical trends and ecological interactions
}

\author{
W. M. Kemp ${ }^{1, *}$, W. R. Boynton ${ }^{2}$, J. E. Adolf ${ }^{1}$, D. F. Boesch ${ }^{3}$, W. C. Boicourt ${ }^{1}$, G. Brush ${ }^{4}$, \\ J. C. Cornwell ${ }^{1}$, T. R. Fisher ${ }^{1}$, P. M. Glibert ${ }^{1}$, J. D. Hagy ${ }^{5}$, L. W. Harding ${ }^{1}$, E. D. Houde ${ }^{2}$, \\ D. G. Kimmel ${ }^{1}$, W. D. Miller ${ }^{1}$, R. I. E. Newell ${ }^{1}$, M. R. Roman $^{1}$, E. M. Smith ${ }^{6}$, J. C. Stevenson ${ }^{1}$ \\ ${ }^{1}$ University of Maryland, Center for Environmental Science, Horn Point Laboratory, Cambridge, Maryland 21613, USA \\ ${ }^{2}$ University of Maryland, Center for Environmental Science, Chesapeake Biological Laboratory, Solomons, Maryland 20688, USA \\ ${ }^{3}$ University of Maryland, Center for Environmental Science, Cambridge, Maryland 21613, USA \\ ${ }^{4}$ Johns Hopkins University, Department of Geography \& Environmental Engineering, Baltimore, Maryland 21218, USA \\ ${ }^{5}$ U.S. Environmental Protection Agency, NHEERL, Gulf Ecology Division, Gulf Breeze, Florida 32561, USA \\ ${ }^{6}$ University of South Carolina, Department of Biology, Columbia, South Carolina 29208, USA
}

\begin{abstract}
This review provides an integrated synthesis with timelines and evaluations of ecological responses to eutrophication in Chesapeake Bay, the largest estuary in the USA. Analyses of dated sediment cores reveal initial evidence of organic enrichment in $\sim 200 \mathrm{yr}$ old strata, while signs of increased phytoplankton and decreased water clarity first appeared $\sim 100 \mathrm{yr}$ ago. Severe, recurring deep-water hypoxia and loss of diverse submersed vascular plants were first evident in the 1950s and 1960s, respectively. The degradation of these benthic habitats has contributed to declines in benthic macroinfauna in deep mesohaline regions of the Bay and blue crabs in shallow polyhaline areas. In contrast, copepods, which are heavily consumed in pelagic food chains, are relatively unaffected by nutrient-induced changes in phytoplankton. Intense mortality associated with fisheries and disease have caused a dramatic decline in eastern oyster stocks and associated Bay water filtration, which may have exacerbated eutrophication effects on phytoplankton and water clarity. Extensive tidal marshes, which have served as effective nutrient buffers along the Bay margins, are now being lost with rising sea level. Although the Bay's overall fisheries production has probably not been affected by eutrophication, decreases in the relative contribution of demersal fish and in the efficiency with which primary production is transferred to harvest suggest fundamental shifts in trophic and habitat structures. Bay ecosystem responses to changes in nutrient loading are complicated by non-linear feedback mechanisms, including particle trapping and binding by benthic plants that increase water clarity, and by oxygen effects on benthic nutrient recycling efficiency. Observations in Bay tributaries undergoing recent reductions in nutrient input indicate relatively rapid recovery of some ecosystem functions but lags in the response of others.
\end{abstract}

KEY WORDS: Eutrophication · Nutrients · Chesapeake Bay

Resale or republication not permitted without written consent of the publisher

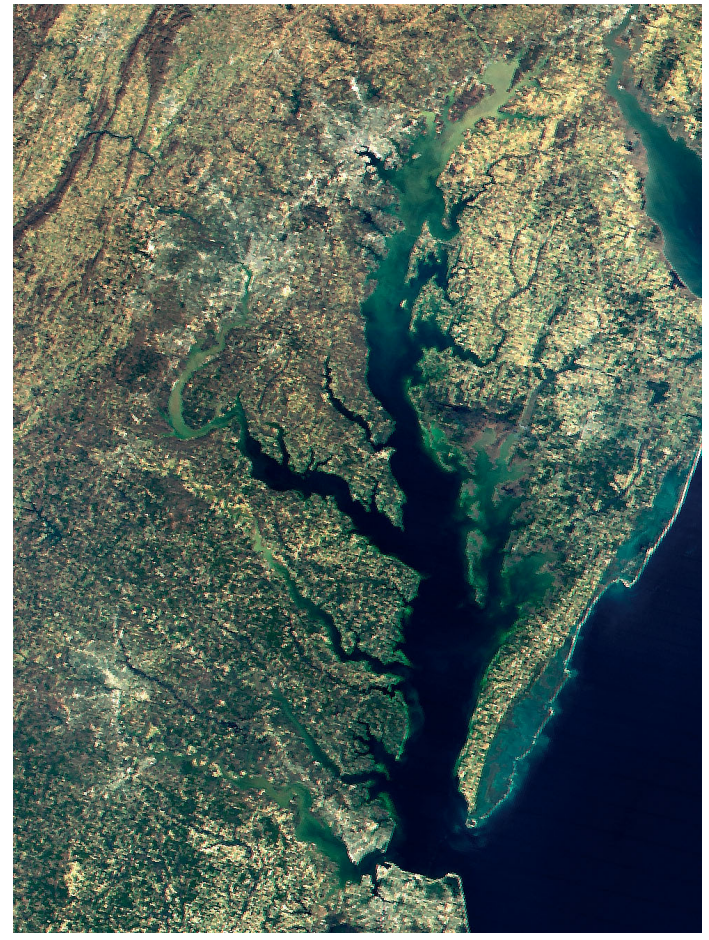

Chesapeake Bay is a large estuary which has undergone many changes in its ecological properties and processes in response to nutrient enrichment over the last 2 centuries. Susceptibility of the Bay to eutrophication arises in part from the long dendritic shoreline that intimately connects it to its large watershed (covering an area 15 times that of the Bay) which contains expanding human population centers and extensive agricultural activities.

(Satellite image from MODIS, http://visibleearth.nasa.gov) 


\section{INTRODUCTION}

Eutrophication studies have played a central role in both basic and applied limnology throughout the last century (Hutchinson 1969, Likens 1972). Until recent decades, however, few such studies had included coastal marine systems (e.g. Nixon 1995), which were often considered invulnerable to effects of nutrient enrichment because of their well-mixed, well-flushed nature (Schindler 1981). By the early to mid-1970s, nutrient-induced increases in algal production and biomass were being reported for a number of coastal marine ecosystems (e.g. Ryther \& Dunstan 1971, Sönderström 1971, Lehmusluoto 1973, Melvasalo et al. 1975). With an ever-increasing proportion of human population being centered in coastal watersheds (Valiela et al. 1992, de Jonge et al. 2002), the problem of eutrophication has become a central theme of coastal research and management at regional and global scales (Jansson 1978, Rosenberg 1985, Gray 1992, Howarth et al. 2000).

The more recent explosion of coastal eutrophication research (e.g. Smetacek et al. 1991, Nixon 1995) has generated a relatively complex conceptual model of estuarine ecosystem responses to nutrient inputs (Cloern 2001). Although in most aquatic ecosystems nutrient enrichment elicits increases in phytoplankton biomass and decreases in water clarity (e.g. Nielsen et al. 2002a), estuarine phytoplankton have exhibited a comparatively greater diversity of bloom-forming species in response to eutrophication (Smith 2003). Nutrient enrichment has contributed to widespread changes in coastal habitats, including loss of seagrasses (e.g. Walker \& McComb 1992, Short \& Wyllie-Echeverria 1996), proliferation of harmful phytoplankton (Smayda 1990) and benthic macroalgae (e.g. Menesguen \& Piriou 1995, Valiela et al. 1997), and depletion of dissolved oxygen in bottom waters (Andersen \& Rydberg 1988, Diaz 2001). Indirect evidence suggests that these habitat effects have altered trophic structures, production, and composition of fish and invertebrate communities through a range of ecological mechanisms (Caddy 1993).

Diverse ecological processes tend to 'buffer' and regulate algal growth in coastal environments. These processes include nutrient assimilation and turbidity reduction by seagrass beds, control of algal biomass by herbivores, and suppressed recycling of $\mathrm{N}$ and $\mathrm{P}$ with elevated oxygen concentrations. Many of these natural buffering mechanisms can, however, be compromised by extreme nutrient enrichment (e.g. Zhang et al. 2003). Once altered, their non-linear nature makes it difficult for these mechanisms to be reestablished (e.g. Scheffer \& Carpenter 2003, Smith 2003). In addition, coastal ecosystems may become more vulnerable to
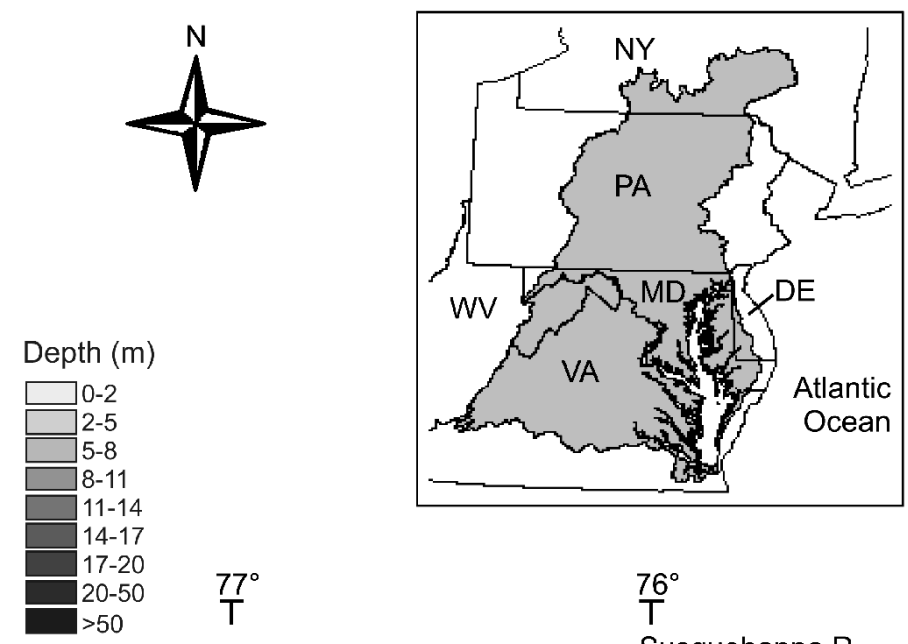

$>50$

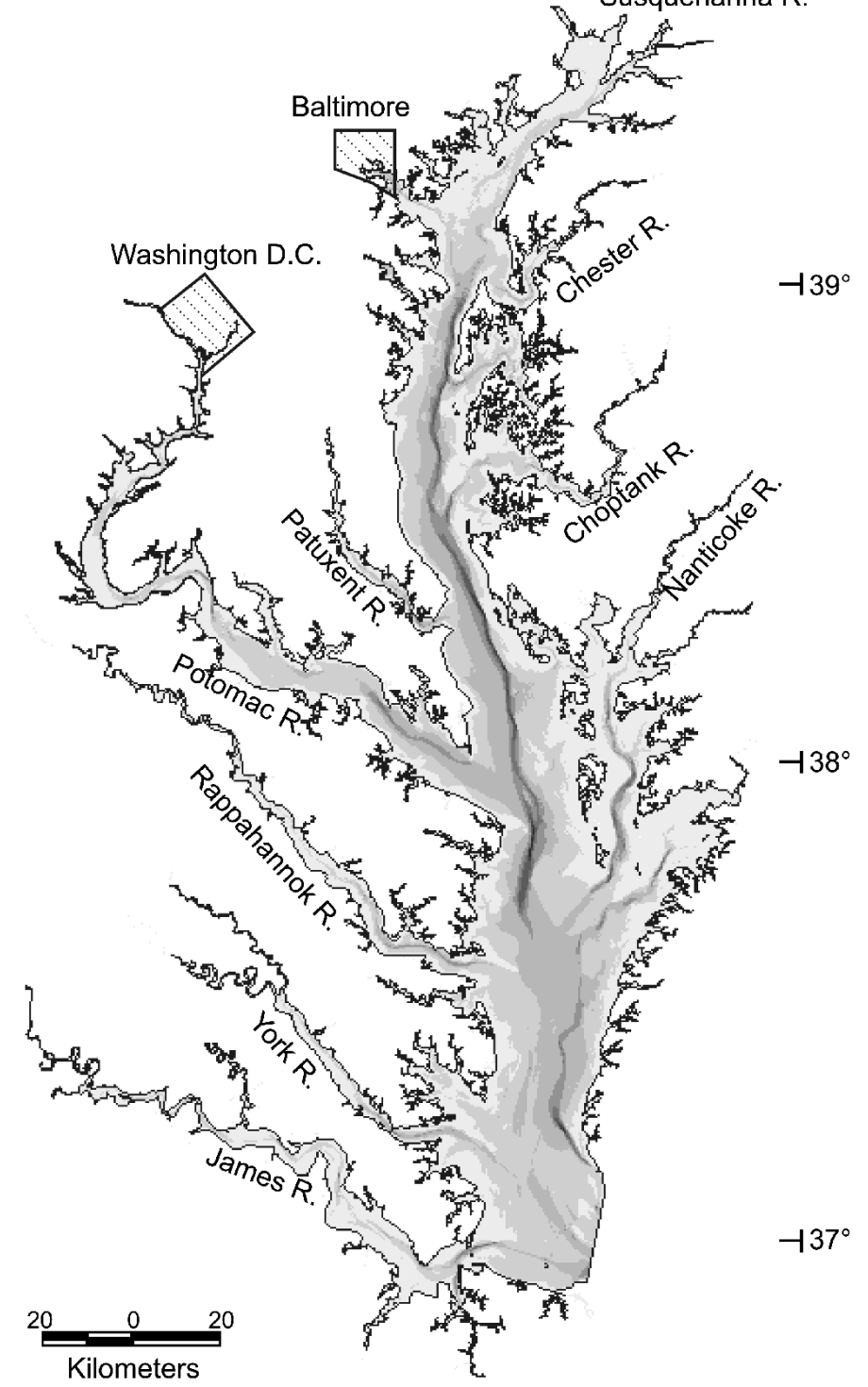

(1)

$\mathrm{T}$

Susquehanna $\mathrm{R}$

Fig. 1. Map of Chesapeake Bay showing water depth and major tributary systems. Inset map indicates location of estuary and watershed 
effects of nutrient enrichment via increases in temperature and river flow associated with climate change (e.g. Justić et al. 1996) and by fishery harvest of key herbivores that otherwise control algal growth (Jackson et al. 2001). While a fully integrated view of coastal eutrophication is just now emerging, it appears that the associated dynamics are highly complex.

Recent reviews have emphasized the global nature of coastal eutrophication, describing broad patterns of ecological responses (e.g. Nixon 1995, Richardson \& Jørgensen 1996). However, Cloern (2001) suggests that estuaries can exhibit substantial differences in magnitude and even trajectory of responses to nutrients, reflecting complex non-linear and estuary-specific ecological interactions. Before we can explain differences among estuaries in their responses to nutrient enrichment, we must review and clarify our understanding of specific systems. Toward that goal, we provide here a synthesis of what we have learned regarding ecological responses to eutrophication in the large well-studied coastal system of Chesapeake Bay, USA.

\section{ESTUARINE CIRCULATION AND GEOMETRY}

Chesapeake Bay is a large estuary located in the USA's mid-Atlantic coastal region. The Bay is almost $300 \mathrm{~km}$ long, with a relatively deep (20 to $30 \mathrm{~m}$ ) and narrow (1 to $4 \mathrm{~km}$ ) central channel confined by a sill at its seaward end (Fig. 1). Broad shallow areas flank the central Bay channel over its entire length (Boicourt et al. 1999), and depths exceeding $10 \mathrm{~m}$ constitute only $24 \%$ of the Bay's surface area $\left(11500 \mathrm{~km}^{2}\right)$, while the mean depth is only $6.5 \mathrm{~m}$ (Fig. 2). The slope of depth vs. area curves (Fig. 2) is steepest for the mid (mesohaline) Bay region compared to the upper (tidal-fresh and oligohaline) and lower (polyhaline) portions of the estuary.

An average of $2300 \mathrm{~m}^{3} \mathrm{~s}^{-1}$ of freshwater flows from the Bay's watershed into its $74.4 \mathrm{~km}^{3}$ water volume, with the Susquehanna River at the head of the Bay providing more than half of the flow (Schubel \& Pritchard 1986). This freshwater input sets up stratification, which isolates deep channel waters by suppressing vertical exchange (Seliger \& Boggs 1988, Boicourt 1992). This 'buoyancy reservoir' acts over relatively long time scales (Fig. 3), where winter-spring Susquehanna River flow controls stratification throughout the summer (Hagy 2002). Strong episodic wind mixing events contribute to periodic destratification (Goodrich et al. 1987), especially in the middle reaches of the Bay. Stratification is, however, quickly reestablished from a buildup of the Bay's longitudinal salinity gradient (Boicourt 1992).

River flow drives the estuarine circulation, characterized by a lower-layer counterflow that acts to retain particulate and dissolved materials in the Bay
(Pritchard 1956, 1967). This circulation creates relatively long residence times (90 to $180 \mathrm{~d}$ ) for freshwater and nutrients. The combination of the Bay's long water residence-time, its stratified water column, and its narrow central channel isolated by sills and flanked by wide shallows make this a productive system, with efficient nutrient use and tendency for depletion of oxygen from deep waters (Boicourt 1992).

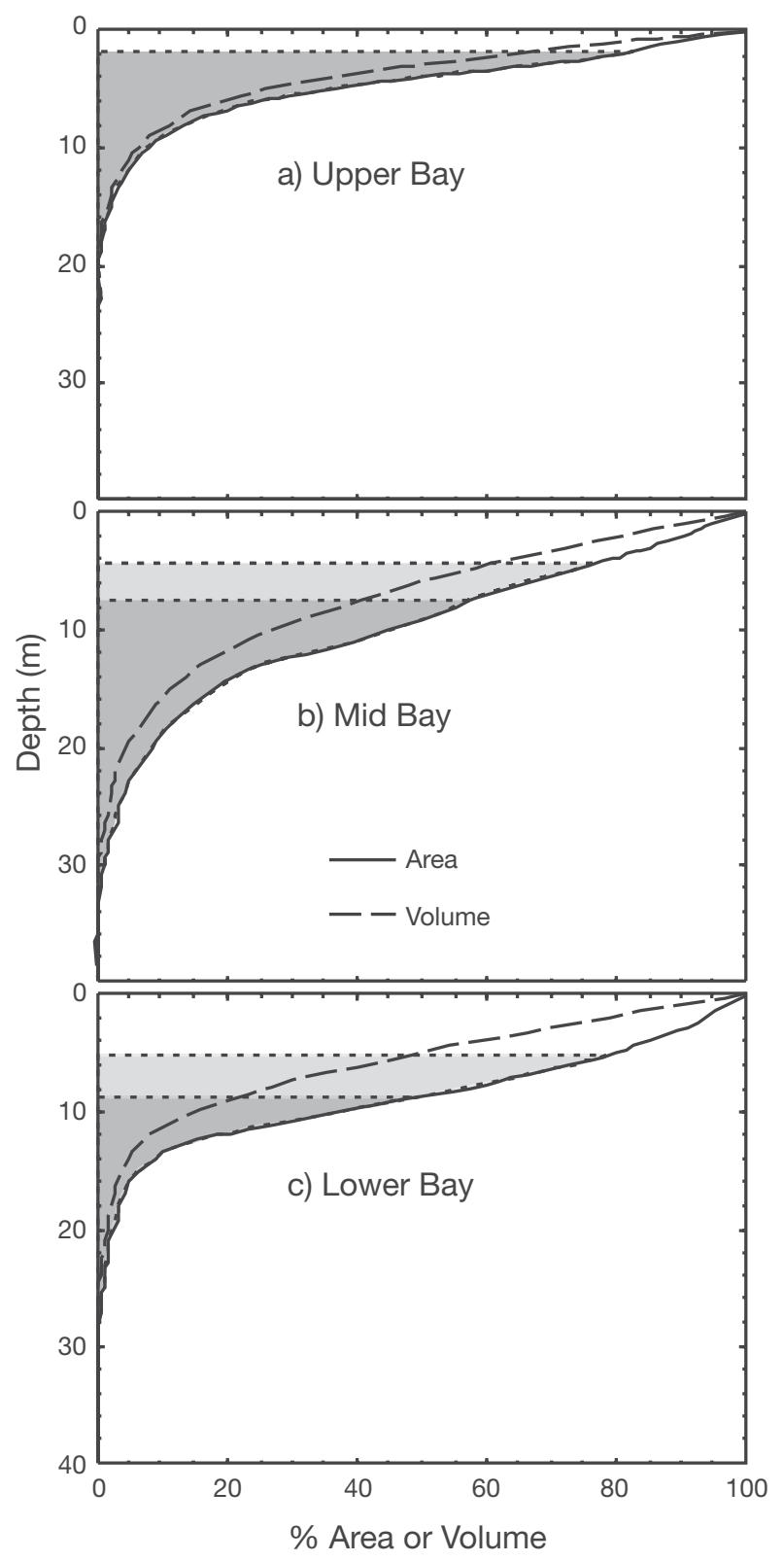

Fig. 2. Hypsographic presentation of distributions of $\%$ total estuarine surface area and \% total water volume below a depth plotted vs. that water column depth for 3 regions of Chesapeake Bay separated by $39.0^{\circ} \mathrm{N}$ and $37.0^{\circ} \mathrm{N}$ latitude. Line defining top of dark shaded area represents estimated mean depth of $1 \%$ surface irradiance $\left(Z_{1 \%}\right)$ in the 1930 s, and line at top of light shaded area represents calculated mean $Z_{1 \%}$ for 1990s (Table 1) 


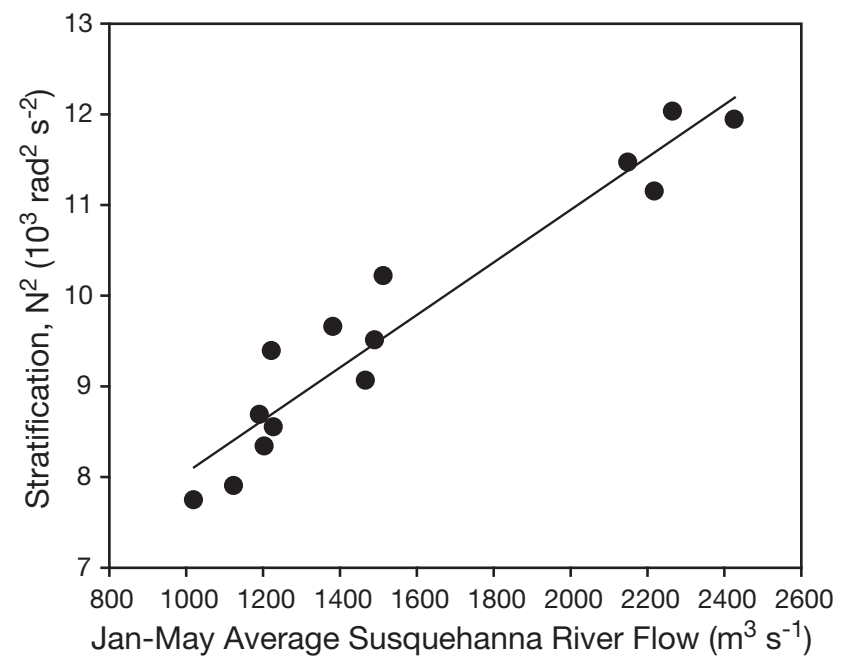

Fig. 3. Relationship between January-May average Susquehanna River flow (1986-1999) and April-September average water column stratification in middle Bay, expressed as average of maximum squared Brunt-Väisälä frequency (N). Indicated line is least-squares regression line $\left(r^{2}=0.90\right)$. Adapted from Hagy (2002)

\section{HISTORICAL PATTERNS OF INPUTS AND WATER QUALITY}

\section{Trends in watershed activities and nutrient loading}

Chesapeake Bay's watershed covers a substantial area $\left(164200 \mathrm{~km}^{2}\right)$ containing diverse ecological and physiographic features and patterns of human settlement. The ratios of the Bay's watershed area to its estuarine water area and volume (14.3 and $2.2 \mathrm{~m}^{-1}$, respectively) are large compared to other estuaries (e.g. Bricker et al. 1999). These features, coupled with the long $(18800 \mathrm{~km})$ dendritic Bay shoreline, render the estuary closely connected with its watershed. When Europeans migrated to this region 4 centuries ago, they encountered a landscape almost completely covered with temperate forests bordered by wetlands (Brush et al. 1980).

During the 400 yr since initial European settlement, the character of the Bay watershed has undergone large changes (Curtin et al. 2001). The number of humans in the watershed has grown exponentially since colonial times (Fig. 4a), with a 3-fold increase evident during the last $100 \mathrm{yr}$. Currently, the drainage basin contains about 16 million people, but average population density remains modest (1 person ha ${ }^{-1}$ ) compared to many other coastal areas worldwide (e.g. Smith et al. 2003a). The initial pattern of land use change was dominated by progressive land clearing for agriculture until the mid-1800s when about half the basin was deforested (Fig. 4b). In the initial phases of
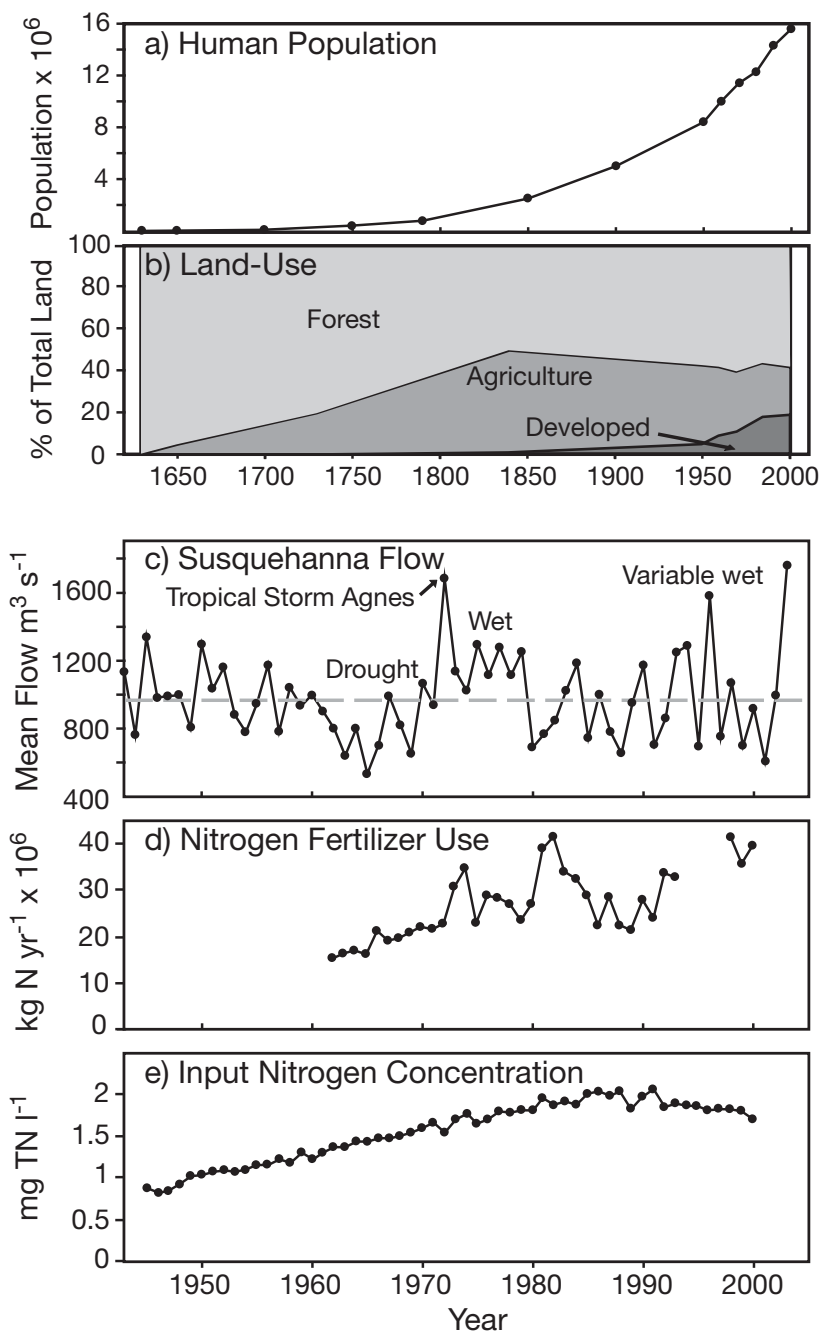

Fig. 4. Historical changes in Chesapeake Bay's watershed in terms of (a) human population and (b) major land uses from 1600 to 2000; also shown are (c) Susquehanna River flow, (d) nitrogen fertilizer use in Maryland, (e) concentrations of total nitrogen at Susquehanna River fall line, 1945 to 2003

land clearing, farmers needed large tracts of land to allow long fallow periods; crop rotation and use of natural fertilizers in the 19th century replaced fallow farming and allowed cultivation of more erodible and less fertile lands. Throughout the last 2 centuries urban land has expanded, while agricultural land has declined, and forested land has gradually increased. Growth of human population in coastal watersheds is a major factor contributing to increased nutrient loading to estuaries throughout the world (Meybeck 1998, Smith et al. 2003a).

Many rivers link the Bay directly to its watershed. During the period of record (1890 to 2004), flow of the largest of these rivers, the Susquehanna (Fig. 4c), has been highly variable at a range of time scales that include short drought periods (e.g. early 1953 to 1955), 
prolonged droughts (e.g. 1960s), huge flood events (e.g. a 200 yr storm, tropical storm Agnes, in 1972), prolonged wet periods (e.g. 1970s), and decades of extreme variability (e.g. 1990s). While there is no longterm trend evident in flows from the Susquehanna or other Bay tributaries, there is some suggestion that interannual variation has increased during the last several decades (Fig. 4c). In general, year-to-year variations in river flow cause fluctuations in inputs and estuarine distributions of freshwater, suspended sediments, and nutrients. These in turn affect stratification and circulation as well as productivity and organism abundance (e.g. Hearn \& Robson 2001, Hagy et al. 2004).

Despite the declining proportion of the Bay's watershed devoted to agriculture since around 1850, use of commercial fertilizers (Fig. 4d) and import of animal feed grew dramatically after the 1950s (Fig. 4d). As a result of growth in fertilizer use and other human activities in the watershed, nutrient loading to the Bay has increased. For example, Susquehanna River concentrations of total $\mathrm{N}$ (TN) entering the Bay increased by 2.5 -fold from 1945 to 1990 , with a small decline during the last decade (Fig. 4e) evidently due to improved watershed land management (Sprague et al. 2000). Similar increases in nutrient loading associated with expanded agricultural activities have been reported for many coastal regions during the last several decades (e.g. Eyre \& Pont 2003, Kauppila et al. 2003).

\section{Sediment record of eutrophication}

Although direct human observations are not available to describe temporal trends in the Bay ecosystem at multicentury scales, a rich indirect ecological record exists within the Bay's sediments. These trends have been quantified and interpreted in recent studies using geochemical and paleontological methods applied to sediment cores collected throughout the estuary (e.g. Brush \& Brush 1994). The history of eutrophication of Chesapeake Bay during the nearly 400 yr since European colonization has received particular emphasis (e.g. Brush 1984).

Over the course of recent decades, 300 dated sediment cores have been collected from Chesapeake Bay and its tributaries. These cores vary in length from 0.5 to $20 \mathrm{~m}$ and contain histories of sedimentation rates, organic carbon sources, salinity and temperature regimes, $\mathrm{O}_{2}$ conditions, and biological changes evidenced in microfossil assemblages and plant seeds over the last $12000 \mathrm{yr}$ (Colman et al. 2002). Time lines have been established in cores using isotopic tracers (e.g. ${ }^{14} \mathrm{C},{ }^{210} \mathrm{~Pb}$ ) and event horizons (e.g. ${ }^{137} \mathrm{Ce}$ and ragweed pollen). Representative data series for key biotic and geochemical indices are presented to illustrate patterns of eutrophication of the Bay during the centuries since European colonization (Fig. 5). The first signs of human disturbance were evident in the 17 th and 18th centuries (Fig. 5), with rapidly increasing sedimentation rates (Brush 1989, Cronin \& Vann 2003). Concomitant increases in burial of both total organic carbon (associated with terrestrial and aquatic plants) and biogenic silica (associated with planktonic diatoms) provide early evidence of eutrophication (Colman \& Bratton 2003).

The sedimentary record also provides key indices of eutrophication-induced changes in the structure of the estuarine ecosystem. For example, although rates of bacterial carbon burial exhibited little change over the first 3 centuries of record (Fig. 5), a sharp increase was evident starting in the mid-20th century (Zimmerman \& Canuel 2000), with parallel increases in the ratio of bacterial carbon to biogenic silica possibly reflecting a decline in the efficiency at which diatom production is transferred to upper trophic levels (e.g. Kemp et al. 2001). During the same time period, a pronounced shift in the ratio of centric (planktonic) to pennate (typically benthic) diatoms in the preserved record (Fig. 5)

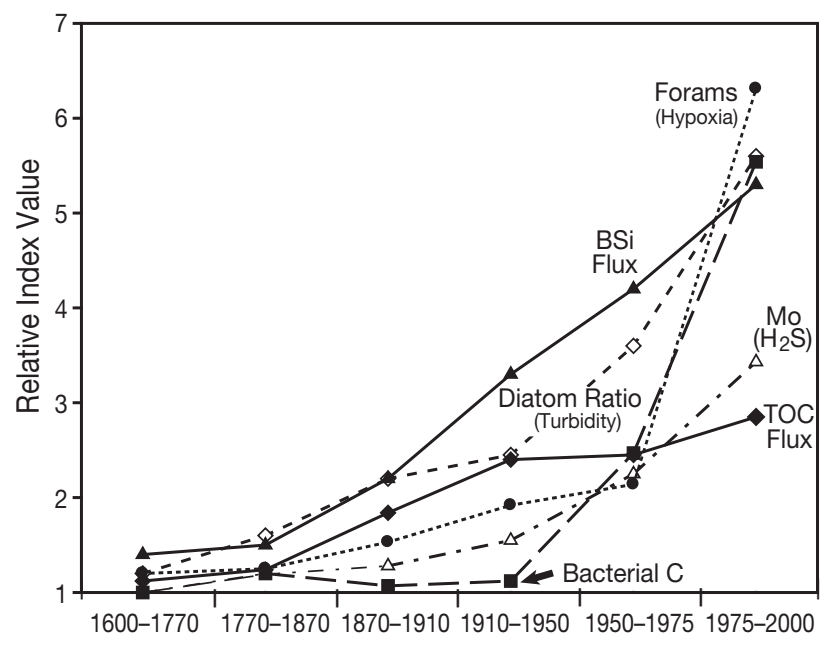

Fig. 5. Comparison of indicators of eutrophication in sedimentary record of deep channel of mesohaline Chesapeake Bay. 'Relative index values' are calculated as ratio of each index value (rate, concentration, ratio) for each date to mean value calculated for precolonial (pre-17th century) conditions. Parameters and sources of data used are: total organic carbon (TOC) mass flux corrected for degradation (Zimmerman \& Canuel 2002; their Fig. 6, cores RD and M3); delivery factors for bacterial organic carbon (Zimmerman \& Canuel 2000, their Fig. 10); incorporation of biogenic silica (BSi; Colman \& Bratton 2003); ratio of centric to pennate diatoms (Cooper 1995, their Fig. 8); concentration of molybdenum (Mo; Adelson et al. 2001, their Fig. 5, cores 55 and PC-6); and percentage (compared to a baseline of $<10 \%$ ) of total benthic Foraminifera (Forams) comprised of a hypoxia-tolerant species, Ammonia parkinsoniana (Karlsen et al. 2000, their Figs. 12 \& 13) 
reflects decreases in both water clarity and benthic algal production (Cooper \& Brush 1993). These trends may have initiated the general shift from a largely benthic estuarine ecosystem to one dominated by planktonic processes.

Most sedimentary indicators suggest that the increased occurrence of bottom-water hypoxia and anoxia in the main-stem Bay is a relatively recent phenomenon. Although a few indices, such as dinoflagellate cyst formation rate (Willard et al. 2003), provide earlier signs of hypoxia, the majority of reported biotic and geochemical indicators show that the intense and recurrent seasonal depletion of $\mathrm{O}_{2}$ is relatively unique to the last 50 yr. For example, solid-phase molybdenum formation rates (which are proportional to sulfide concentrations, Adelson et al. 2001) and the proportion of total foraminifera fossil abundance comprised of the hypoxia-tolerant species Ammonia parkinsoniana (Karlsen et al. 2000) both exhibited steep increases since the early to mid-20th century (Fig. 5). Similar trends have been shown for other indices of bottomwater hypoxia, including the degree of pyritization of iron (Cooper \& Brush 1991, 1993) and the ratio of acidvolatile sulfur to chromium reducible sulfur (Zimmerman \& Canuel 2002).

\section{PRIMARY PRODUCERS AND BIOGEOCHEMISTRY}

\section{Nutrient inputs, concentrations, and fates}

Current estimates of total nitrogen (TN) and phosphorus (TP) loads (per estuarine area) to Chesapeake Bay and its tributaries average about $14 \mathrm{~g} \mathrm{~N} \mathrm{~m}^{-2} \mathrm{yr}^{-1}$ and $1.1 \mathrm{~g} \mathrm{P} \mathrm{m}^{-2} \mathrm{yr}^{-1}$, respectively (Boynton et al. 1995). These values vary by a factor of 2 between wet and dry years (Hagy et al. 2004) and are intermediate compared to those of other estuarine systems (Billen et al. 1991, de Jonge et al. 1994, Nixon et al. 1996). Much higher rates of nutrient inputs (e.g. $100 \mathrm{~g} \mathrm{~N} \mathrm{~m}^{-2} \mathrm{yr}^{-1}$ ) in urban tributaries (e.g. near Baltimore) promote very high summer planktonic chlorophyll-a (chl-a) concentrations $\left(>250 \mu \mathrm{g} \mathrm{l}^{-1}\right)$. As shown for other coastal systems (e.g. Borum 1996), interannual variations in loading rates are reflected by nutrient concentrations in the estuary, with specific relationships between loading and concentrations often differing among systems (Fig. 6).

A mass-balance analysis of sources and sinks for total $\mathrm{N}$ and total $\mathrm{P}$ in Chesapeake Bay and 4 major tributaries indicated several consistent patterns (Boynton et al. 1995). The seasonally varying ratio of TN:TP watershed inputs to the Bay has been gradually increasing in recent decades (Hagy et al. 2004). For the whole Bay, diffuse watershed sources repre-

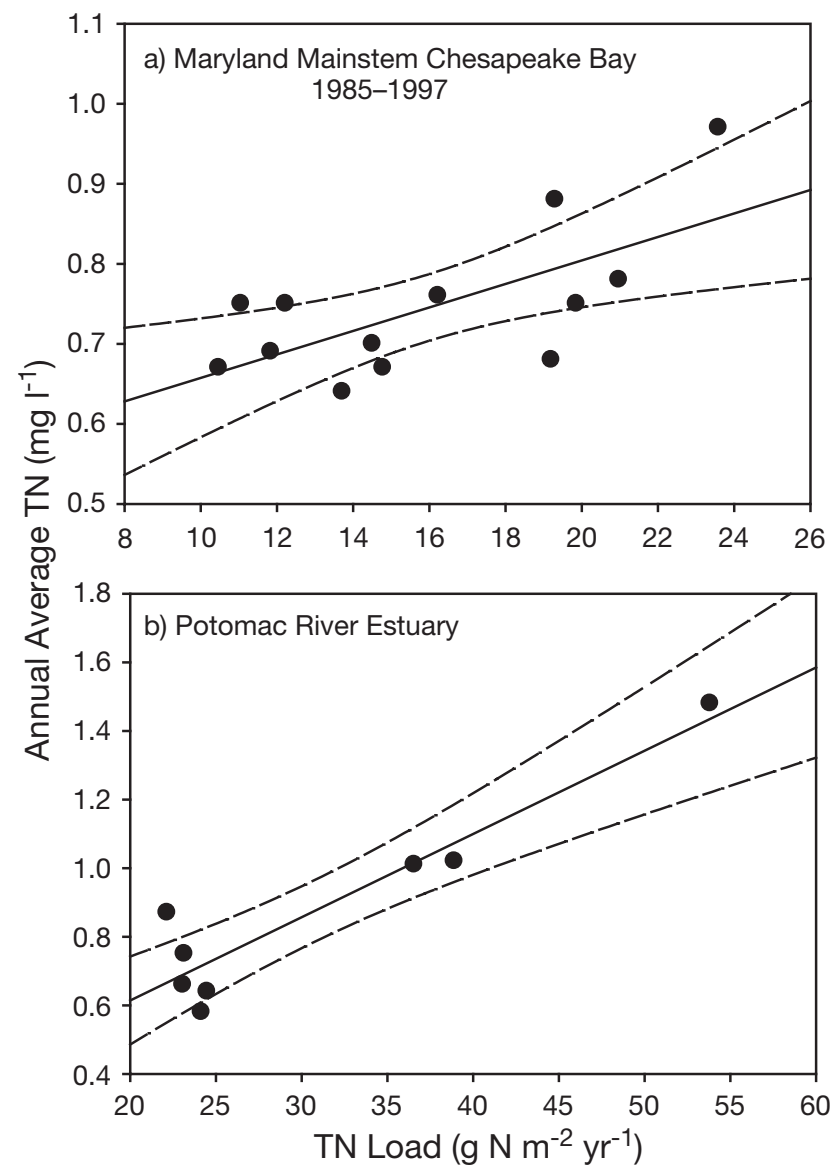

Fig. 6. Relationship between annual mean concentrations of total nitrogen concentration (TN) and TN loading for (a) main stem of Chesapeake Bay and (b) Potomac River estuarine tributary

sented $60 \%$ and $58 \%$, while direct atmospheric deposition comprised $12 \%$ and $6.5 \%$ of TN and TP inputs, respectively. The remainder of the nutrient inputs are derived primarily from watershed point sources for $\mathrm{TN}$, while oceanic inputs provide an additional source ( $37 \%$ of the total) for TP. The dominant loss terms for the estuarine $\mathrm{N}$ budget are denitrification (26\% of TN inputs) and long-term burial $(35 \%)$, while burial is the primary loss term for P. Losses due to commercial and recreational fisheries are small for $\mathrm{N}(9 \%)$ and smaller yet for $\mathrm{P}(5 \%)$. These values vary somewhat among tributary subestuaries, but it is clear that, in contrast to some estuaries, the Bay does not act like a pipe conveying nutrients directly to the adjacent ocean (Borum 1996, Nixon et al. 1996). Whereas most of the TN and TP inputs to the Bay are inorganic forms, $\mathrm{N}$ and $\mathrm{P}$ exported to coastal waters are largely organic, indicating active uptake and transformation of nutrient inputs and a positive net primary production in the Bay ecosystem (Kemp et al. 1997). 


\section{Phytoplankton biomass and community composition}

Increased abundance of phytoplankton is an early manifestation of eutrophication in many aquatic ecosystems (e.g. Smith 2003). Although rates of diatom production and burial in Chesapeake Bay sediments appear to have increased steadily since the early 19th century (Fig. 5), recent historical analysis of direct measurements of phytoplankton chl-a (Harding 1994, Harding \& Perry 1997) reveal that surface mixed-layer concentrations also increased significantly between 1950 and 1994, with the polyhaline regions showing the largest changes. Extensive monitoring data collected since 1994 have enabled an updating of these trends (Fig. 7). Chl-a increased 1.5- to 2-fold in oligohaline and mesohaline regions peaking in the 1960s (Fig. 7a,b) and 5- to 13-fold in the polyhaline region of the Bay from the 1950s to the 1980s (Fig. 7c). Chl-a has decreased in the upper oligohaline region since the 1970s (Fig. 7a) in response to relatively high turbidity (e.g. Fisher et al. 1999, Harding et al. 2002) associated with elevated river flow (Fig. 4). Although no temporal trends in chl-a are evident in the main-stem Bay from 1985 to 2004, significant increases and decreases are apparent in various tributaries (www.eyesonthebay.net).

This pattern-phytoplankton chl-a increasing between the 1950s and 1980s and unchanged during the last decade-corresponds to reported trends in $\mathrm{N}$ loading to the Bay during this period (Fig. 4e). Similar relationships between temporal trends in nutrient loading and chl-a have been reported for other coastal environments (e.g. Radach 1992, Cadee 1992). Comparative analyses among estuaries around the world have also revealed broad positive relationships between nutrient loading or concentration and algal production and/or biomass (e.g. Boynton et al. 1982, Monbet 1992, Nixon et al. 1996). Primary productivity of the whole ecosystem (planktonic plus benthic) may, however, saturate at relatively lower nutrient inputs (Borum \& Sand-Jensen 1996).

As demonstrated in various coastal environments experiencing increased nutrient loading (e.g. Cederwall \& Elmgren 1990, Cadee 1992), direct microscope analyses of Bay waters have revealed general trends of shifts in phytoplankton community dominance from larger to smaller cells (e.g. Marshall 1994). Although few historical direct observations are available to examine possible shifts in phytoplankton community structure, paleobotanical studies reveal increases in the ratio of centric-to-pennate diatoms during the last 2 centuries (Cooper \& Brush 1991, Cooper 1995). In addition, analysis of sediment cores indicates that relative abundances of dinoflagellates, cyanobacteria, and small flagellates appear to have increased significantly during the last half century (Zimmerman \& Canuel 2002).

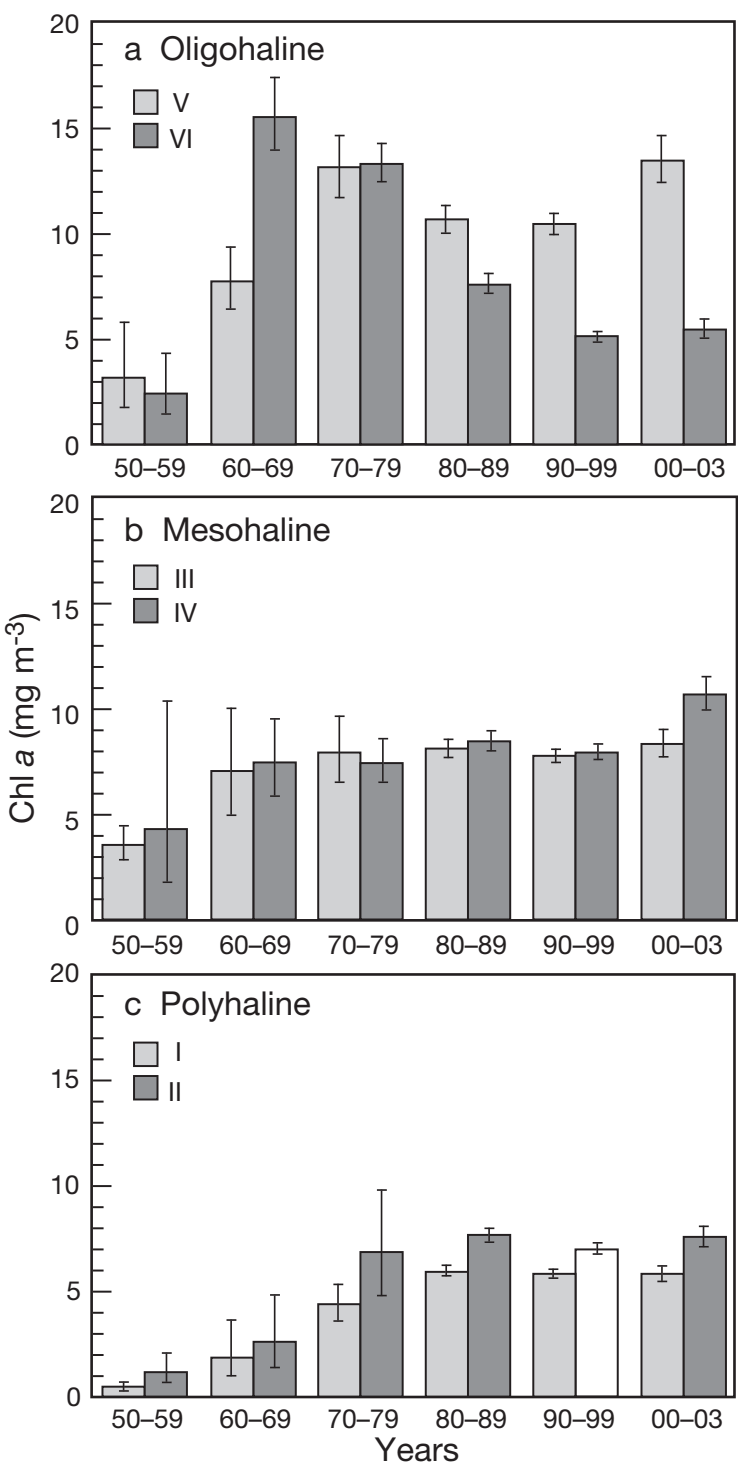

Fig. 7. Historical changes in annual mean surface layer concentrations of phytoplankton chlorophyll-a. Data are organized into 6 previously defined segments (numbered consecutively from ocean to land) along axis of main-stem Bay (Harding 1994), and these are grouped into 3 major salinity regions (oligohaline, mesohaline, polyhaline)

In some instances, eutrophication-induced shifts in phytoplankton communities involve enhanced growth of algal species that cause direct harmful effects, including production of toxins, noxious discoloration, and floating mucilage (e.g. Paerl 1988, Smayda 1990 Anderson et al. 2002). Although factors causing these harmful algal blooms (HABs) are complex, many have been associated with nutrient enrichment (e.g. Cadee \& Hegeman 1986, Lukatelich \& McComb 1986, Smayda 1997). There are numerous instances where HABs have been reported in Chesapeake Bay and its tributaries, and several appear to be related directly 
to nutrient inputs. For example, in the oligohaline Potomac River estuary (Fig. 1), frequency of summer blooms of the toxic cyanobacterium Microcystis aeruginosa declined sharply in the early 1970 s when $\mathrm{P}$ removal from sewage was initiated (Sellner et al. 1988, Jaworski 1990). Although other HAB outbreaks in the Bay have been more difficult to relate directly to nutrient enrichment, blooms of both the common Bay dinoflagellate Prorocentrum minimum and the rarer mixotrophic dinoflagellate Pfiesteria piscicida appear to be stimulated by addition of dissolved organic nitrogen (DON) including urea and humic acids (Glibert et al. 2001, Heil 2005). In addition, 'brown tide' blooms of the small pelagophyte Aureococcus anophagefferens, which occur in shallow coastal lagoons (Bricelj \& Lonsdale 1997) including those adjacent to Chesapeake Bay (Lomas et al. 2001, Trice et al. 2004), have also been linked to DON enrichment (Berg et al. 1997). Cells of P. minimum and $A$. anophagefferens inhibit growth of shellfish (Luckenbach et al. 1993, Bricelj \& Lonsdale 1997), while P. piscicida produces a lethal neurotoxin (e.g. Burkholder \& Glasgow 1997).

\section{Depletion of bottom-water oxygen}

Organic matter produced in phytoplankton blooms sinks into deep Bay waters where it is decomposed in oxygenconsuming processes. The increasing frequency and magnitude of seasonal oxygen $\left(\mathrm{O}_{2}\right)$ depletion from bottom waters is a phenomenon linked closely with anthropogenic nutrient enrichment in Chesapeake Bay and elsewhere (e.g. Rosenberg 1990, Johannessen \& Dahl 1996). Direct measurements, however, indicate that hypoxia $\left(<2.0 \mathrm{mg} \mathrm{O}_{2} \mathrm{l}^{-1}\right)$ occurred occasionally in deep waters of the main-stem Bay even in the 1930s (Newcombe \& Horne 1938, Newcombe et al. 1939). Although reports in the 1980s suggested historical trends of increasing Bay hypoxia (Officer et al. 1984), these patterns were questioned (Seliger \& Boggs 1988), largely because of the overriding effect of interannual variations in river flow on stratification (e.g. Fig. 3). A recent analysis of data collected between 1950 and 2001 supports both contentions (Hagy et al. 2004). Despite the significant correlations ob- served between time-integrated volume of hypoxic (and anoxic, $<0.2 \mathrm{mg} \mathrm{O} \mathrm{O}^{-1}$ ) water and winter-spring river flow (Fig. 8a), trend analysis revealed that, consistent with patterns in sedimentary records (Fig. 5), significant increases in severity and spatial extent of hypoxia have occurred since the 1950s.

The spatial distribution and seasonal development of hypoxia in Chesapeake Bay illustrate that $\mathrm{O}_{2}$ depletion arises from interactions between biological and physical processes (Taft et al. 1980, Kemp et al. 1992). Hypoxia develops in the Bay's bottom layer, appearing first in late spring at the northern limit of the stratified flow and expanding southward as summer unfolds.
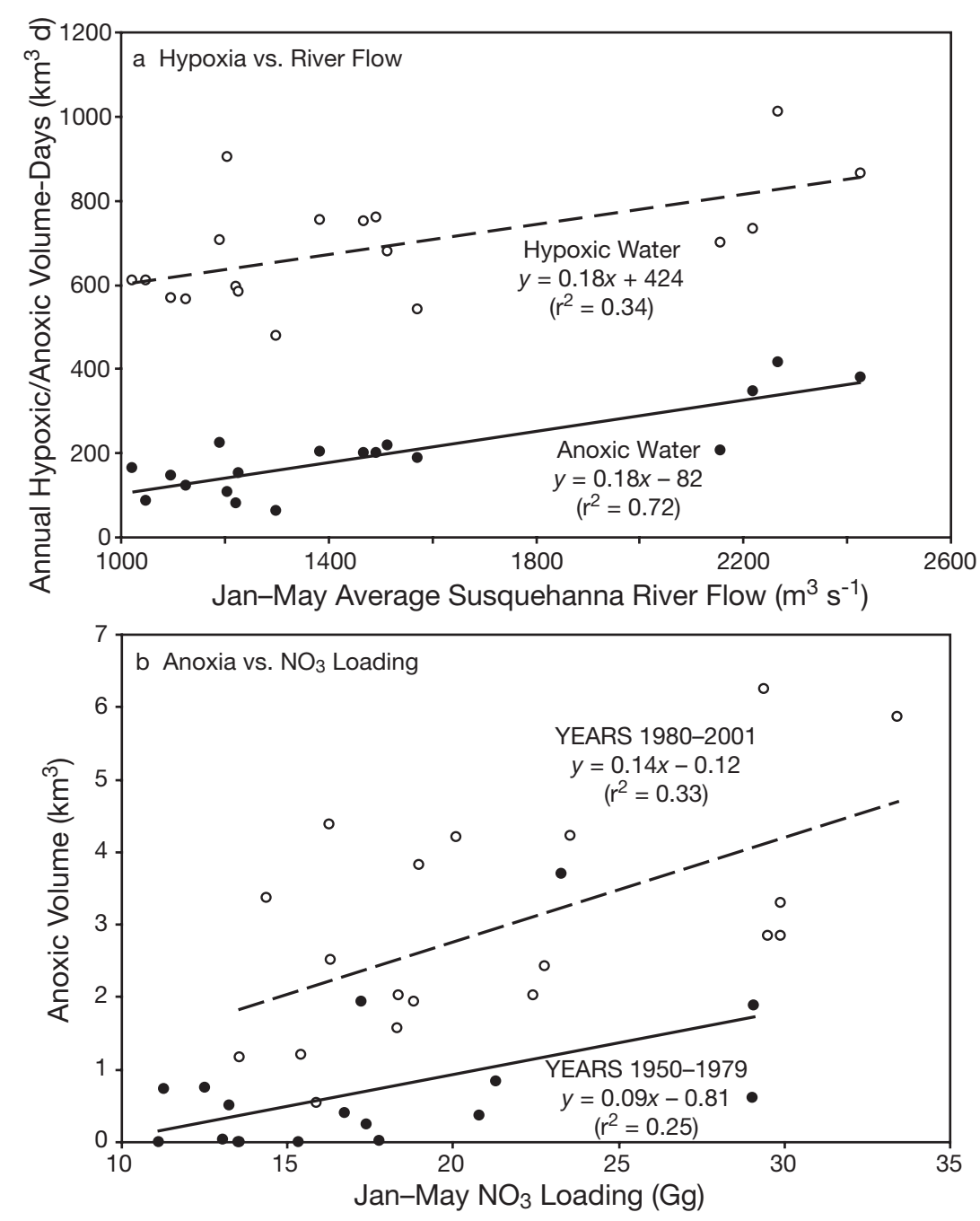

Fig. 8. Trends in volume of low $\mathrm{O}_{2}$ bottom water in mesohaline region of mainstem Chesapeake Bay. (a) Variations in time-integrated summer volume of hypoxic $\left(\mathrm{O}_{2}<2 \mathrm{mg} \mathrm{l}^{-1}\right)$ water (dashed line, open circles) and anoxic (operationally $\mathrm{O}_{2} \leq 0.2 \mathrm{mg} \mathrm{l}^{-1}$ ) water (solid line, closed circles) from 1984 to 2003 vs. mean winter-spring flow of Susquehanna River, and (b) midsummer volume of anoxic bottom water vs. winter-spring nitrate loading from Susquehanna River for earlier years (1950-1979, solid line, filled circles) and for later years (1980-2001, dashed line, open circles). Modified from Hagy et al. (2004) 
The timing of $\mathrm{O}_{2}$ depletion in spring is predicted by freshwater inflow, which regulates water column stratification and associated rates of $\mathrm{O}_{2}$ replenishment, and by spring water temperature, which affects respiration rates (Hagy et al. 2004). Interannual variations in spring nutrient loading have also been correlated with rates of organic deposition to sediments (Boynton \& Kemp 2000), which would be expected to promote increased $\mathrm{O}_{2}$ demand. Initial springtime rates of $\mathrm{O}_{2}$ decline have, however, varied little since 1938 (Hagy et al. 2004). This suggests that the initial spring decline in $\mathrm{O}_{2}$ is strongly controlled by physical processes, while the late spring $\mathrm{O}_{2}$ decline and the extent of summer hypoxia are more closely related to eutrophication (Hagy et al. 2004).

It is difficult to resolve the relative roles of nutrient inputs and other factors in the development of summer hypoxia from a short time series of data. It is clear that human activities from 1950 to the present have significantly changed $\mathrm{N}$ loading to the Bay (Fig. 4d,e). Since both hypoxia and $\mathrm{N}$ loading have increased over time, the two are correlated. Unexpectedly, however, it appears that hypoxia has tended to be more severe in recent years even at equivalent levels of $\mathrm{N}$ loading (Hagy et al. 2004). In fact, there are 2 separate significant relationships between hypoxia and nitrate loading for earlier (1950-1979) and later (1980-2001) years, with similar slopes but very different intercepts (Fig. 8b). This implies that the Bay has become less able to assimilate $\mathrm{N}$ inputs without developing hypoxia, a change that may have arisen from the degradation of key ecological processes sensitive to eutrophication effects. Potential mechanisms include (1) loss of benthic plant biomass due to increased turbidity and loss of oyster biomass, both of which tend to retain nutrients and organic matter in shallow waters; (2) increased efficiency of $\mathrm{N}$ and $\mathrm{P}$ recycling with marked decreases in denitrification and $\mathrm{P}$ precipitation in response to recent severe and persistent hypoxia.

\section{Redox-induced changes in sediment biogeochemistry}

Depletion of $\mathrm{O}_{2}$ from bottom waters causes a decrease in the oxidation-reduction potential (redox condition), which changes the fundamental nature of sediment biogeochemistry and nutrient cycling processes (e.g. Stumm \& Morgan 1970). Even under normoxic $\left(>3 \mathrm{mg} \mathrm{O}_{2} \mathrm{l}^{-1}\right.$ ) conditions, sulfate $\left(\mathrm{SO}_{4}\right)$ is the dominant terminal electron acceptor supporting benthic respiration throughout much of the Bay; especially during summer hypoxia when $\mathrm{SO}_{4}$ reduction rates are very high (Roden \& Tuttle 1993, Marvin-DiPasquale \& Capone 1998). Accumulation of aqueous Fe(II) and Mn(II) in subpycnocline waters (Gavis \& Grant 1986) indicates that these metals may also serve as respiratory electron acceptors or (as with $\mathrm{O}_{2}$ ) as oxidants of reduced sulfur generated from sulfate reduction. Although rapid formation of iron sulfide minerals occurs under anoxia during summer months, the complete 'titration' of iron oxides by reduced sulfur (Cornwell \& Sampou 1995) results in a summer efflux of 65 to $95 \%$ of the reduced sulfur to the overlying water (Roden \& Tuttle 1992), where it exerts a substantial $\mathrm{O}_{2}$ demand (Kemp et al. 1992).

In general, low redox conditions result in elevated effluxes of ammonium $\left(\mathrm{NH}_{4}\right)$ and phosphate $\left(\mathrm{PO}_{4}\right)$ from sediments to overlying water. As has long been reported for lakes (e.g. Einsele 1936, Mortimer 1941), release of $\mathrm{PO}_{4}$ from sediments is enhanced under anoxic conditions in deep regions of Chesapeake Bay (e.g. Cowan \& Boynton 1996). In contrast, Bay sediments in shoal areas above the pycnocline seldom exhibit high rates of $\mathrm{PO}_{4}$ release (Boynton \& Kemp 1985, Reay et al. 1995), except under conditions of abnormally high $\mathrm{pH}$ (Seitzinger 1991). Under anoxic conditions, the dissolution of near-surface iron oxides and/or their conversion to iron sulfides (Cornwell \& Sampou 1995) tends to coincide with the onset of high $\mathrm{PO}_{4}$ effluxes from sediments. In the mesohaline region of the Bay, effluxes of $\mathrm{PO}_{4}$ from sediments are 5-fold larger when bottom water $\mathrm{O}_{2}$ is $<1.5 \mathrm{mg} \mathrm{l}^{-1}$ (Fig. 9a). Similarly, the fraction of remineralized $\mathrm{NH}_{4}$ that is recycled from sediments to overlying water is also controlled by redox conditions (Fig. 9b). Whereas virtually all regenerated $\mathrm{NH}_{4}$ diffuses into the overlying water under anaerobic conditions, nitrifying bacteria oxidize a substantial fraction of this $\mathrm{NH}_{4}$ to nitrate $\left(\mathrm{NO}_{3}\right)$ when $\mathrm{O}_{2}$ is present, leading to subsequent reduction to $\mathrm{N}_{2}$ (e.g. Graco et al. 2001). Nitrifying bacteria require $\mathrm{O}_{2}$, and their activity is inhibited by the elevated concentrations of hydrogen sulfide that typically accompany anoxia (Henriksen \& Kemp 1988, Joye \& Hollibaugh 1995). In the mesohaline Bay, rates of nitrification are high in spring and fall when bottom waters are oxygenated but are negligible during midsummer anoxia (Kemp et al. 1990). Consequently, the ratio of $\mathrm{NH}_{4}$ recycling to total efflux of inorganic $\mathrm{N}$ solutes $\left(\mathrm{NH}_{4}+\mathrm{N}_{2}+\mathrm{NO}_{3}\right)$ tends to be inversely related to bottom-water $\mathrm{O}_{2}$ concentrations (Fig. 9b).

The enhanced efficiency of $\mathrm{NH}_{4}$ and $\mathrm{PO}_{4}$ release from $\mathrm{O}_{2}$-stressed sediments represents an important biogeochemical feedback mechanism that reinforces the eutrophication process. Increased phytoplankton production associated with nutrient enrichment leads to bottom-water $\mathrm{O}_{2}$ depletion, which in turn increases the rate and efficiency of nutrient recycling from sediments to the euphotic zone, thereby amplifying eutrophication. Negative effects of hypoxia on the physical-chemical processes that control $\mathrm{PO}_{4}$ recycling 

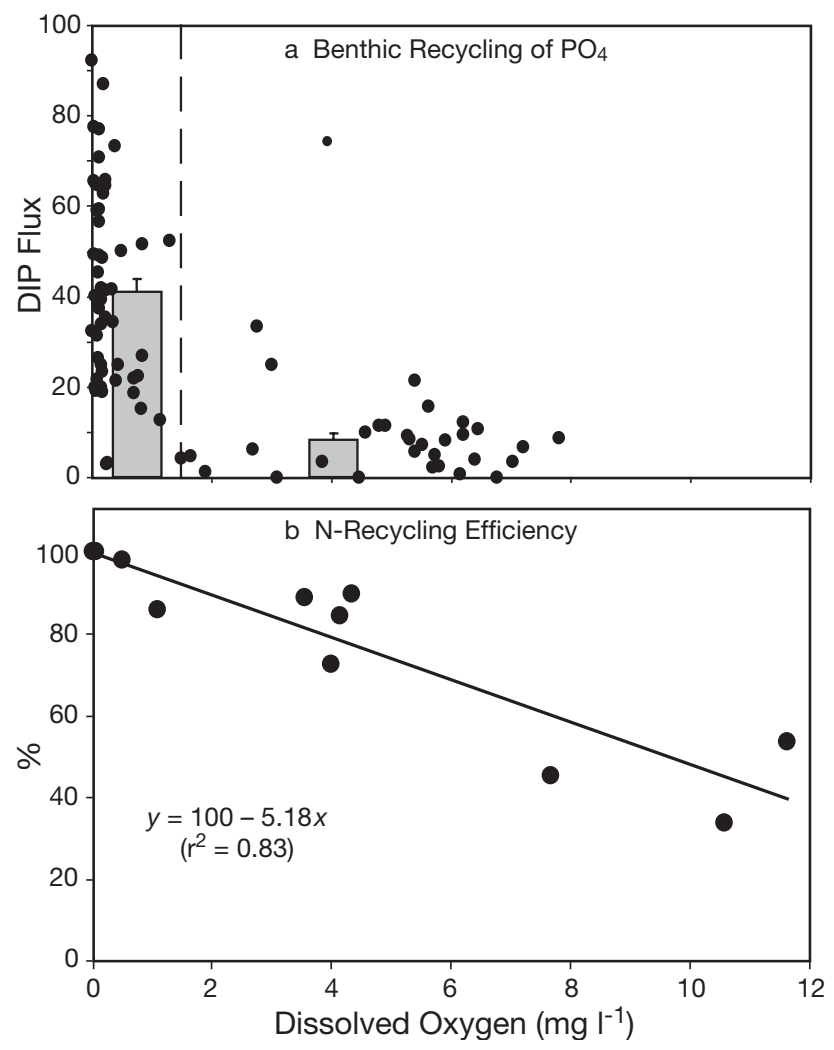

Fig. 9. Relationships between bottom-water $\mathrm{O}_{2}$ concentrations and benthic nutrient recycling for (a) effluxes of $\mathrm{PO}_{4}$ from sediments to overlying water, where histograms indicate mean and standard error for fluxes at $\mathrm{O}_{2}<1.5 \mathrm{mg} \mathrm{l}^{-1}$ and $\mathrm{O}_{2}>$ $1.5 \mathrm{mg} \mathrm{l}^{-1}$ (W. Boynton et al. unpubl.) and (b) percentage of total inorganic $\mathrm{N}$ efflux from sediments accounted for by DIN efflux (J. Cornwell et al. unpubl.). Measurements were made in mesohaline locations in Chesapeake Bay and its tributaries during spring and summer

can be reversed within hours with restoration of high $\mathrm{O}_{2}$ levels, while recovery of nitrifying bacteria from anoxia effects can take weeks to months. Longer-term (years to decades) impacts of chronic low $\mathrm{O}_{2}$ conditions on $\mathrm{PO}_{4}$ and $\mathrm{NH}_{4}$ recycling may arise from anoxiainduced reductions in abundance, size, and activity of benthic bioirrigating macrofauna (e.g. Schaffner et al. 1992). For example, feeding and burrowing activities of many benthic macrofaunal species tend to oxygenate sediments, which effectively reduces nutrient recycling efficiency, particularly for $\mathrm{NH}_{4}$ (e.g. Pelegri et al. 1994, Mayer et al. 1995).

\section{Declining water clarity and benthic microalgal production}

Water clarity. An important and direct consequence of eutrophication is decreased water clarity and reduction in light available for benthic primary production (e.g. Nielsen et al. 2002a). On the other hand, turbidity in some systems may be controlled more by physical conditions including watershed soil erosion and resuspension of bottom sediments (e.g. Cloern 1987). While anthropogenic sediment loading contributed substantially to Chesapeake Bay turbidity in the 18th and 19th centuries (e.g. Roberts \& Pierce 1974), watershed inputs of sediment have declined dramatically since the 1940s (e.g. Brush 1989). In addition, bottom resuspension associated with sediment dredging and demersal fishing tends to produce only localized and ephemeral increases in Bay turbidity (e.g. Ruffin 1998). Consequently, light attenuation in many estuarine regions such as the middle and lower Bay is largely controlled by interactions between plankton and suspended sediments (e.g. Gallegos 2001). Sharp declines in Bay water clarity during spring and summer can be directly related to algal blooms stimulated by watershed nutrient inputs (Gallegos \& Jordan 2002). Reductions in depth distribution of conspicuous benthic plants (e.g. seagrasses, macroalgae) often provide direct evidence of eutrophication impacts on water clarity and benthic primary production (e.g. Giesen et al. 1990, Nielsen et al. 2002b, Kemp et al. 2004). Although parallel reductions in benthic microalgal production certainly occur, these are commonly overlooked (e.g. Rizzo et al. 1992, Fear et al. 2004).

There are surprisingly few data on water clarity prior to the 1940s. Limited historical secchi depth $\left(Z_{\mathrm{sd}}\right)$ measurements collected routinely in plankton studies, however, reveal dramatic increases in turbidity between 1930 and 1970 (e.g. Heinle et al. 1980, D'Elia et al. 2003). A large compilation of such $Z_{\text {sd }}$ data for the Patuxent estuarine tributary (Stankelis et al. 2003, W. Boynton unpubl. data) indicates that water clarity was better in the late 1930s than in the 1960s and slightly better in the 1990s compared to the 1960s (Fig. 10). Although changes in water clarity from the 1930s to the 1960s were muted in the lower salinity regions (6 to 10), substantial decreases in $Z_{\text {sd }}$ are evident in the more saline $(>10)$ part of this Bay tributary (Fig. 10). These data are consistent with anecdotal observations, which suggest dramatically clearer waters in the lower Patuxent estuary prior to 1945 (e.g. Klingel 1951).

Benthic primary production. There are few direct measurements of benthic microalgal production in the contemporary Bay (e.g. Rizzo \& Wetzel 1985, Murray \& Wetzel 1987, Reay et al. 1995) and none prior to 1940. Compelling indirect evidence, however, indicates that there has been a fundamental shift in the contribution of benthic microalgae to total Bay primary production during the last century. As reviewed above, paleoecological evidence reveals contemporaneous decreases in benthic diatoms and increases in various indices of eutrophication during the last century (Fig. 5). Presum- 
ably, nutrient enrichment has promoted an overall increase in production and biomass of phytoplankton, which have contributed to decreases in both water clarity and growth of benthic diatoms. Although benthic microalgal production may actually increase with nutrient loading in some very shallow estuaries (e.g. de Jonge 1990), similar nutrient-induced shifts from benthic to planktonic microalgal production have been widely reported for other estuaries (Nielsen et al. 2002b) and for lakes (Vadeboncoeur et al. 2003).

Recent analyses suggest that benthic microalgal production presently contributes less than $10 \%$ of the total primary productivity in Chesapeake Bay (Kemp et al. 1999). Here, we extend these calculations, which combine data on light attenuation and depth-area geometry (Fig. 2) with benthic photosynthesis-irradiance relationships, to estimate benthic microalgal productivity when the Bay was less eutrophic. Assuming that the relative changes (from the 1930s to the 1990s) in $Z_{\text {sd }}$ for regions in the Patuxent River estuary (Fig. 10) hold for the entire Bay, we computed decreases in light reaching the sediment surface. In this heuristic calculation we also estimated integrated values for recent and historical rates of benthic microalgal production in 3 Bay regions (Table 1). Although we assume no change in benthic production in the low salinity region, it is estimated that rates decreased by about $50 \%$ in the middle and

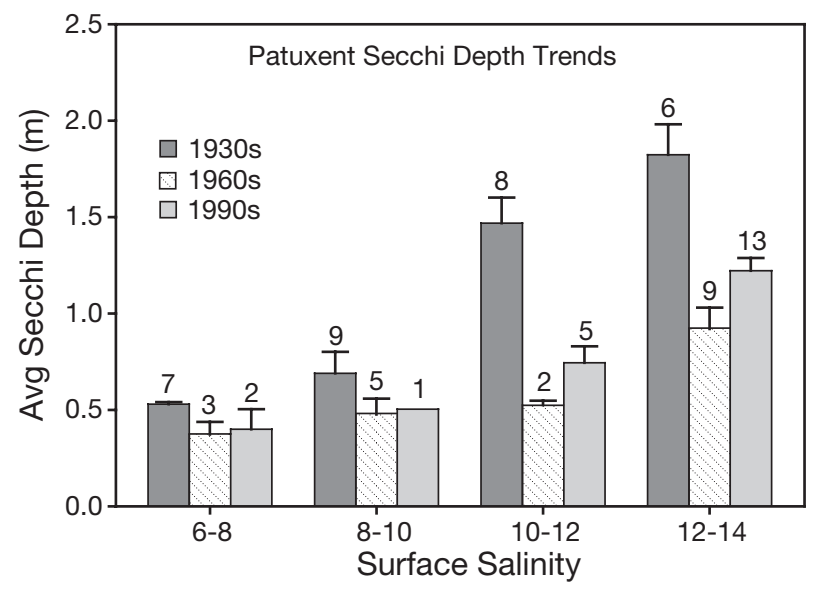

Fig. 10. Variations in mean (+SE) Secchi disk depth observations in the Patuxent River estuary during 3 decades (1930s, 1960s, 1990s) along salinity gradient (data from Stankelis et al. 2003, W. Boynton unpubl). Values above each histogram indicate number of measurements available for that time period and estuarine region
Table 1. Summary of annual mean values for depth of $1 \%$ light penetration $\left(Z_{1} \%\right)$, surface area of bottom shallower than $Z_{1} \%$, and benthic microalgal gross primary production (Benthic GPP) estimated for 1930s and 1990s in 3 main-stem regions of Chesapeake Bay

\begin{tabular}{|c|c|c|c|c|}
\hline Era & Region $^{\mathrm{a}}$ & $\begin{array}{c}Z_{1 \%}{ }^{\mathrm{b}} \\
(\mathrm{m})\end{array}$ & $\begin{array}{l}\text { Bottom area }{ }^{\mathrm{c}}<Z_{1} \% \\
\qquad\left(10^{6} \mathrm{~m}^{2}\right)\end{array}$ & $\begin{array}{l}\text { Benthic GPP } \\
\left(10^{9} \mathrm{~g} \mathrm{C} \mathrm{yr}^{-1}\right)\end{array}$ \\
\hline $1930 \mathrm{~s}$ & $\begin{array}{l}\text { Upper Bay } \\
\text { Middle Bay } \\
\text { Lower Bay } \\
\text { Total Bay }\end{array}$ & $\begin{array}{l}1.7 \\
7.6 \\
8.8 \\
7.6\end{array}$ & $\begin{array}{r}101 \\
828 \\
1508 \\
2508\end{array}$ & $\begin{array}{r}18 \\
137 \\
210 \\
396\end{array}$ \\
\hline $1990 \mathrm{~s}$ & $\begin{array}{l}\text { Upper Bay } \\
\text { Middle Bay } \\
\text { Lower Bay } \\
\text { Total Bay }\end{array}$ & $\begin{array}{l}1.7 \\
4.5 \\
5.2 \\
4.6\end{array}$ & $\begin{array}{r}101 \\
461 \\
649 \\
1365\end{array}$ & $\begin{array}{r}18 \\
77 \\
99 \\
217\end{array}$ \\
\hline \multicolumn{5}{|c|}{$\begin{array}{l}{ }^{\mathrm{a}} \text { Upper Bay defined as main stem area from } 39.0-39.5^{\circ} \mathrm{N} \text {; Mid Bay as } \\
37.9-39.0^{\circ} \mathrm{N} \text {; Lower Bay as } 37.0-37.9^{\circ} \mathrm{N}\end{array}$} \\
\hline \multicolumn{5}{|c|}{$\begin{array}{l}\text { b } 1990 \text { s data from } 15 \text { to } 20 \text { stations in main stem Bay sampled seasonally } \\
\text { for light attenuation coefficient from 1995-1999. 1930s data estimated } \\
\text { by adjusting } 1990 \text { s means to reflect historical changes similar to those } \\
\text { observed in the Patuxent River (Fig. 10). Total Bay values based on } \\
\text { area-weighted mean of regional values }\end{array}$} \\
\hline \multicolumn{5}{|c|}{$\begin{array}{l}{ }^{\mathrm{c}} \text { Areas calculated from regional hypsographic data (Fig. 2) from Cronin } \\
\text { \& Pritchard (1975) }\end{array}$} \\
\hline \multicolumn{5}{|c|}{$\begin{array}{l}{ }^{\mathrm{d}} \text { Calculated from estimated light attenuation data, an annual average } \\
\text { production vs. irradiance relationship empirically derived from sedi- } \\
\text { ment } \mathrm{O}_{2} \text {-flux data collected in the Middle Bay region from 1994-1995 } \\
\text { (Kemp unpubl.), annual mean surface light data (Fisher et al. 2003), and } \\
\text { integrated by multiplying } \mathrm{m}^{2} \text { rates by area at } 1 \text { m depth intervals then } \\
\text { summing over total depth for each region }\end{array}$} \\
\hline
\end{tabular}

lower Bay. If we further assume that phytoplankton productivity was similar in the 1930s and 1950s and contemporary Bay-wide mean values for chlorophyllspecific production have not changed (Harding et al. 2002), we estimate that between the 1930s and 1990s the ratios of benthic-to-planktonic microalgal rates of primary production have declined from 0.3 to 0.1 and from 1.4 to 0.1 in the middle and lower Bay, respectively. This marked shift in the polyhaline Bay is largely attributable to the broad shallow areas flanking this region's central channel (Fig. 2). These estimated declines in benthic-to-planktonic production ratios would be larger still if we had considered the likely increases in phytoplankton productivity from the 1930s to the 1950s as well as the additional loss of water clarity that has probably occurred with declining oyster and seagrass populations (see below).

It is, thus, probable that the balance of ecosystem production was very different in the 1930s, with benthic autotrophs playing a major role. Compared to plankton, benthic microalgal communities (including bacteria, meiofauna, and macrofauna) tend to use and retain nutrients far more efficiently, with relatively small effluxes of $\mathrm{NH}_{4}$ and $\mathrm{PO}_{4}$ from sediments (Tyler et al. 2003) and low rates of denitrification (e.g. Sundbäck et al. 2000). Thus, in systems dominated by benthic autotrophs nutrient resources generate relatively high 
rates of primary production per unit nutrient inputs. Mucous excretion by benthic diatoms and depositfeeding invertebrates tends to bind surface sediments reducing resuspension and turbidity (Madsen et al. 1993), while benthic microalgae production also supports efficient demersal food chains (Miller et al. 1996).

\section{Loss of submersed vascular plants}

The shoal areas of Chesapeake Bay, which historically harbored abundant and diverse communities of seagrasses and other submersed vascular plants, have experienced dramatic changes in plant density and distribution during the last $50 \mathrm{yr}$ (Kemp et al. 1983, Orth \& Moore 1983). Many plant species have declined, including at least 15 salt-tolerant freshwater species in the upper Bay, the seagrass Zostera marina in polyhaline regions, and the euryhaline seagrass Ruppia maritima throughout much of the estuary. In one broad shallow upper Bay area, for example, the initial decline in plants (1960s) was preceded by prolific growth of the exotic Myriophyllum spicatum, which itself eventually disappeared along with the native species by the mid-1970s (Fig. 11a). As noted elsewhere (e.g. Marba \& Duarte 1997), interannual differences in the Bay's plant abundance are related to climatic events, such as the 1972 tropical storm Agnes, which deposited a large volume of sediments over the upper Bay (Schubel \& Hirschberg 1978).

Although prior to 1985 there were very few reported large-scale multispecies losses of submersed plants from coastal habitats (e.g. Den Hartog \& Polderman 1975), such declines of submersed plants in lakes had already been attributed to eutrophication and associated shading from algal growth (e.g. Jupp \& Spence 1977, Phillips et al. 1978). These reports motivated Bay research of submersed plant responses to nutrient enrichment. Studies in experimental estuarine ponds (Kemp et al. 1983, Twilley et al. 1985) showed that nutrient addition led to significant decreases in submersed plant growth that could be directly explained by shading from increased phytoplankton and epiphyte biomass (Fig. 11b). Subsequent mesocosm experiments supported these observations for many species (e.g. Neckles et al. 1993, Neundorfer \& Kemp 1993, Sturgis \& Murray 1997, Moore \& Wetzel 2000). Significant correlations between plant abundance and water quality throughout the Bay corroborated experimental results (Dennison et al. 1993, Stevenson et al. 1993). Studies elsewhere reported similar results (e.g. SandJensen \& Borum 1991, Short et al. 1995), leading to widespread recognition that submersed plant losses in response to coastal eutrophication were global in scale (Duarte 1995, Short \& Wyllie-Echeverria 1996).
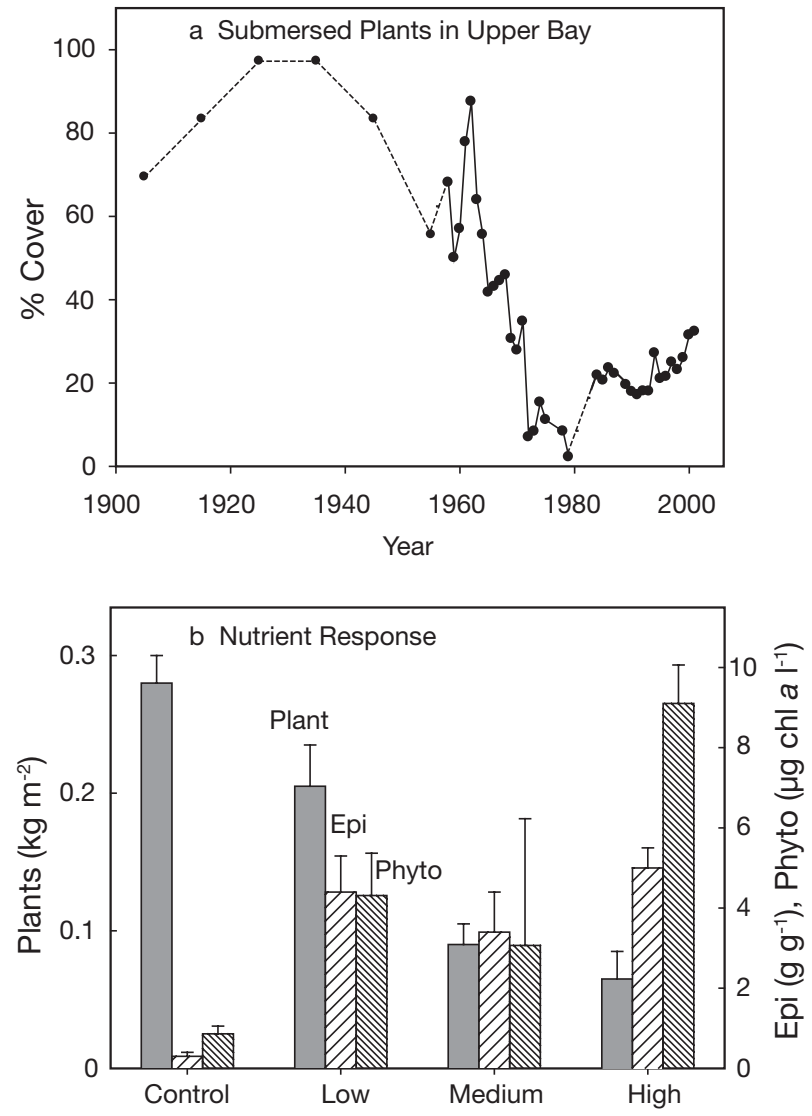

Fig. 11. Variations in submersed vascular plants in upper and mid Chesapeake Bay. (a) Historical changes in relative abundance of submersed plants at an upper Bay site (Susquehanna Flats) from 1900 to 2000. Data from 1900 to 1955 based on seed abundance in dated sediment cores (Brush \& Hilgartner 2000); data from 1955 to 1973 are adapted from Bayley et al. (1978); data from 1974 to 2000 are from Chesapeake Bay Program (www.chesapeakebay.net); (b) variations in biomass of submersed plants, epiphytic algae (Epi) and phytoplankton (Phyto) in triplicate experimental estuarine ponds under different nutrient loading rates, from low $(0.4 \mathrm{~g} \mathrm{~N}$ and $0.09 \mathrm{~g} \mathrm{P}$ $\mathrm{m}^{-2} \mathrm{~d}^{-1}$ ) to high (1.7 $\mathrm{g} \mathrm{N}$ and $0.4 \mathrm{~g} \mathrm{P} \mathrm{m}^{-2} \mathrm{~d}^{-1}$ ), plus controls with ambient water (adapted from Kemp et al. 1983)

Submersed plant beds influence many ecological processes in coastal areas (e.g. Walker et al. 2001). In Chesapeake Bay these plants provide food and habitat for diverse animal populations (Lubbers et al. 1990), including the economically valuable blue crab Callinectes sapidus (Orth \& van Montfrans 1990). Submersed plants also affect biogeochemical processes by enhancing net deposition of suspended particles (Ward et al. 1984, Rybicki et al. 1997), thereby increasing water clarity, benthic photosynthesis, and nutrient assimilation (Kemp et al. 1984). Submersed plants also release $\mathrm{O}_{2}$ from roots to the surrounding rhizosphere, stimulating $\mathrm{N}$ loss via coupled nitrification-denitrification (Caffrey \& Kemp 1990, 1992). For various seagrasses, the trapping of particles and direct assimila- 
tion of solutes from overlying water have been shown to be important terms in the $\mathrm{N}$ and $\mathrm{P}$ budgets of these beds (e.g. Hemminga et al. 1991, Risgaard-Petersen et al. 1998). Few studies have, however, attempted to place such rate calculations in the context of estuaryscale nutrient budgets. Drawing from earlier work (Kemp et al. 1984), we develop here a mass-balance analysis to illustrate the quantitative importance of these beds as sinks in the $\mathrm{N}$ budget of the entire upper Bay (Table 2). If submersed plant beds were restored to historical levels of areal coverage (i.e. most areas $<2 \mathrm{~m}$ mean depth, Kemp et al. 2004), they would remove almost $45 \%$ of the current $\mathrm{N}$ inputs to the upper Bay from watershed and atmospheric sources, with most of this attributable to particle trapping and direct assimilation. Even partial restoration of these plant beds would, thus, substantially help to mitigate effects of nutrient loading.

There is evidence of modest recovery of submersed plants in the upper Bay (Fig. 11a) and other estuarine regions during the last $20 \mathrm{yr}$, especially in tributaries where nutrient levels have been declining (Glibert \& Magnien 2004). A decade of post-Agnes sediment stabilization and an extended drought in the late 1980s (Fig. 4) may have allowed partial reestablishment of submersed plant species, such as Ruppia maritima and Zostera marina, which reproduce proficiently by seeds

Table 2. Estimated influence of submersed vascular plants on nitrogen budget for 'restored' plant communities in upper Chesapeake Bay ${ }^{a}$

\begin{tabular}{|c|c|c|c|}
\hline \multirow{2}{*}{$\begin{array}{l}\text { N-sources or sinks } \\
\text { Nitrogen inputs }^{\mathrm{b}}\end{array}$} & \multicolumn{3}{|c|}{$\begin{array}{l}\mathrm{N} \text {-fluxes } \\
\left(10^{6} \mathrm{~kg} \mathrm{~N} \mathrm{yr}^{-1}\right) \quad(\% \text { of input })\end{array}$} \\
\hline & & & \\
\hline Point discharges & 19.2 & 24 & Boynton et al. (1995) \\
\hline Diffuse loads & 55.2 & 68 & Boynton et al. (1995) \\
\hline Atmospheric deposits & 6.2 & 8 & Boynton et al. (1995) \\
\hline Total input & 80.6 & 100 & \\
\hline \multicolumn{4}{|l|}{ Plant nitrogen sinks } \\
\hline Assimilation $^{\mathrm{c}}$ & 12.1 & 15 & Kemp et al. (1984 \\
\hline Denitrification $^{\mathrm{d}}$ & 1.7 & 2 & Caffrey \& Kemp (1992) \\
\hline Sediment $\mathrm{N}$ trapping ${ }^{\mathrm{e}}$ & 22.4 & 28 & Ward et al. (1984) \\
\hline Total plant sink & 36.2 & 45 & \\
\hline \multicolumn{4}{|c|}{$\begin{array}{l}\text { a Upper main-stem Bay defined as that region above latitude } 38^{\circ} \mathrm{N} \text { excluding } \\
\text { major tributaries. Area of this region is } 3.9 \times 10^{9} \mathrm{~m}^{2} \text {, and potential habitat of } \\
\text { submersed plant communities 'restored' to historical levels would cover } \\
0.56 \times 10^{9} \mathrm{~m}^{2} \text { (Kemp et al. 1999, 2004) }\end{array}$} \\
\hline \multicolumn{4}{|c|}{$\begin{array}{l}\text { bData taken directly from Table } 3 \text { in Boynton et al. (1995) for 'Maryland } \\
\text { Mainstem' }\end{array}$} \\
\hline \multicolumn{4}{|c|}{$\begin{array}{l}{ }^{c} \text { Assumes an estimated annual primary production rate of } 360 \mathrm{~g} \mathrm{C} \mathrm{m}^{-2} \mathrm{yr}^{-1} \\
\text { (Kemp et al. 1984) and a tissue C:N molar ratio of } 19 \text { (Caffrey \& Kemp 1990) }\end{array}$} \\
\hline \multicolumn{4}{|c|}{$\begin{array}{l}\text { dPlant 'enhancement' of sediment denitrification taken as difference be- } \\
\text { tween rates measured in vegetated and unvegetated sediments }(1.8 \mathrm{mmol} \\
\mathrm{N} \mathrm{m}^{-2} \mathrm{~d}^{-1} \text {, Caffrey \& Kemp 1990, 1992) for a } 4 \text { mo growing season }\end{array}$} \\
\hline \multicolumn{4}{|c|}{$\begin{array}{l}{ }^{\mathrm{e}} \text { Based on plant-enhanced sedimentation of } 0.2 \mathrm{~cm} \mathrm{mo}^{-1} \text { for a } 4 \text { mo } \\
\text { growing season, with sediment dry bulk density of } 1 \mathrm{~g} \mathrm{~cm}^{-3} \text { and } \mathrm{N} \text { content } \\
\text { of } 0.5 \% \text { dry wt (Ward et al. 1984) }\end{array}$} \\
\hline
\end{tabular}

(e.g. Verhoeven 1979, Harwell \& Orth 2002). However, many Bay regions remain devoid of seagrasses, and many historically dominant plant species remain scarce. In any case, it is clear from field and modeling studies that widespread recovery of submersed plants in the Bay must begin with reduced nutrient levels and increased water clarity.

\section{Loss of tidal marshes as nutrient buffers}

There has long been scientific interest in understanding patterns of net nutrient exchanges between tidal marshes and adjacent estuaries (e.g. Nixon 1980, Dankers et al. 1984, Valiela et al. 2000). Recent studies suggest that, as with submersed plants, many tidal marshes are capable of buffering eutrophication effects by trapping and assimilating nutrients and by stimulating denitrification at the margins of estuaries (Bricker \& Stevenson 1996). Although early Chesapeake Bay studies of nutrient fluxes in marsh tidal creeks failed to show clear patterns of nutrient removal at tidal scales (e.g. Heinle \& Flemer 1976, Stevenson et al. 1977), recent measurements and mass-balance analyses suggest that Bay marshes can be major nutrient sinks. For example, particulate $\mathrm{N}$ and $\mathrm{P}$ trapped in marshes of the tidal fresh Patuxent represent 35\% and $80 \%$ of the respective inputs to the upper estuary (Merrill \& Cornwell 2000). Furthermore, rates of denitrification and $\mathrm{N}$ assimilation in fringing tidal marshes have been estimated to remove almost $80 \%$ of the groundwater $\mathrm{N}$ inputs to a smaller Bay tributary (Stevenson et al. 2002).

During the 17th century, land clearance in the Bay watershed was limited to small tobacco fields surrounded by thick vegetation. Consequently, little sediment escaped the land (Stevenson et al. 1999, Brush \& Hilgartner 2000). By the end of the 18th century, however, many streams were choked with sediment resulting from the increase in agricultural land and a shift from tobacco to wheat farming (Cronon 1983). Interestingly, this led to a large 19th century expansion of the Bay's tidal marshes, particularly in low- and mid-salinity estuarine regions (Froomer 1980). Early maps, for example, suggest that the areal extent of marshes on the Bay's eastern shore continued to grow until 1900 (peaking at $>40000 \mathrm{ha}$ ) but stabilized thereafter as sea-level rise accelerated from $\sim 0.5$ to 
$3 \mathrm{~mm} \mathrm{yr}{ }^{-1}$ between the 17 th century and the present (Kearney 1996, Stevenson \& Kearney 1996). Beginning in the late 20th century, however, many marshes began showing clear signs that they were unable to keep pace with sea-level rise (Stevenson et al. 1985, 2000). Currently, more than $50 \%$ of the Bay's marshes show evidence of deterioration (Kearney et al. 2002).

Present-day erosion of upper and middle Bay tidal marshes is significantly reducing nutrient buffering capacity at the estuarine margins (Kearney et al. 1988, Stevenson et al. 1999). In addition, the release of organic matter and nutrients from these deteriorating marshes (Kemp et al. 1997) may actually be accelerating eutrophication in shallow estuarine environments (Stevenson et al. 2002). For example, severe nighttime hypoxia has been observed in tidal ponds that were once emergent marshes (Stevenson et al. 2002). It is, thus, ironic that many of the Bay's tidal marshes, which were created in the 18th century as a consequence of eroding agricultural lands and became effective nutrient and sediment buffers, are now being lost due to both insufficient upland inputs of sediments and rapidly rising sea level.

\section{FOOD WEBS AND CONSUMER POPULATIONS}

\section{Hypoxia and loss of benthic macroinfauna}

Although direct measurements of benthic macroinfaunal abundance in deep Chesapeake Bay sediments are not available prior to 1950 , the dominance of laminated sediments in long cores (2 to $3 \mathrm{~m}$ ) collected in the mid-Bay channel suggests that bioturbating infauna have been essentially absent from this region for about $100 \mathrm{yr}$ (Schaffner et al. 1992). A shift of dominant macroinfaunal species observed in the early 1960s in deep muddy sediments of a Bay tributary (York River estuary) was attributed to increasing hypoxic stress (Boesch \& Rosenberg 1981). Regular sampling in the mesohaline Bay did not begin until the 1970s (Holland et al. 1977), after severe hypoxia had become well established as an annual feature. Nonetheless, a significant hypoxia-related decrease in benthic macroinfauna was observed during 1971-1984, primarily involving the replacement of larger older bivalves by short-lived opportunistic species (Holland et al. 1987).

In a recent synthesis, Herman et al. (1999) interpreted a significant relationship between benthic macroinfauna biomass and primary productivity in shallow normoxic estuarine systems (Fig. 12) to suggest that these benthic animals tend to be food limited. For the polyhaline lower Bay, measurements of primary productivity and infaunal biomass correspond well with this relationship, while the mean level of infaunal biomass in the upper Bay is also consistent

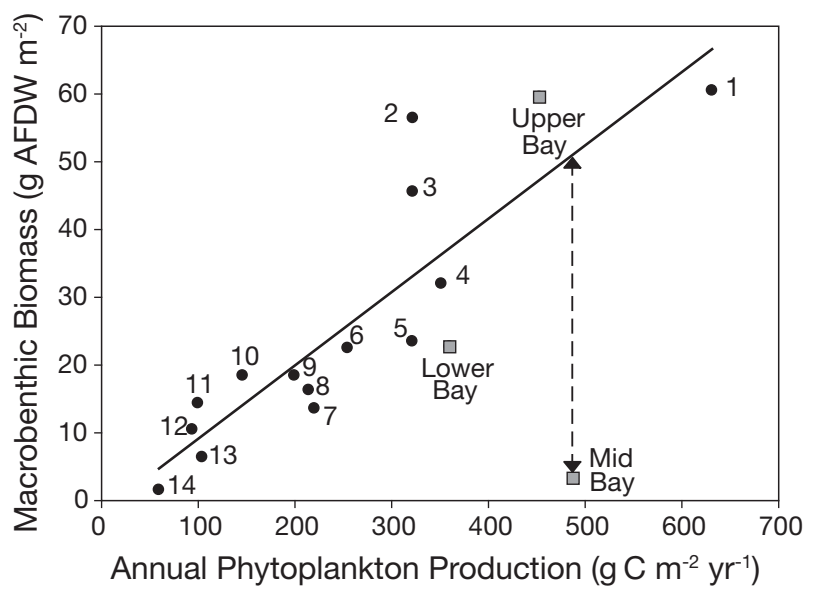

Fig. 12. Relationship between annual mean values of phytoplankton production and macrobenthic biomass in estuaries and coastal systems. The Upper Bay value for primary production includes estimates of allochthonous organic matter inputs from the Susquehanna River. Site locations are as follows: 1 = Ythan Estuary, 2 = Grevelingen, 3 = Oosterschelde, 4 = Balgzand (1980's), 5 = Veerse Meer, 6 = Ems Estuary (Wadden), 7 = Lynher Estuary, $8=$ Long Island Sound, $9=$ San Francisco Bay, 10 = Balgzand (1970s), 11 = Bay of Fundy, $12=$ Westershelde, $13=$ Ems Estuary (inner), $14=$ Columbia Estuary (adapted from Herman et al. 1999 and Hagy 2002)

with this relationship when allochthonous inputs (Kemp et al. 1997) are combined with phytoplankton productivity (Fig. 12). In the middle seasonally hypoxic Bay regions, however, benthic biomass is only $10 \%$ of that expected from this region's high phytoplankton production rates (emphasized by dashed line in Fig. 12). Bioenergetic analyses indicate that, although growth of macrobenthos may be limited by food availability in upper and lower Bay regions (e.g. Thompson \& Schaffner 2001), this is not the case in the mid-Bay, where benthos appear to be degraded (Gerritsen et al. 1994, Hagy 2002). These empirical relationships suggest hypoxia-induced degradation of benthic infaunal in the main-stem Bay (Hagy 2002) as well as in Bay tributaries (Llanso 1992, Dauer et al. 2000). The fact that many of the Bay's historically important macroinfaunal species have limited tolerances to low $\mathrm{O}_{2}$ (Diaz \& Rosenburg 1995) supports this contention. In general, food-limited benthic communities tend to increase with eutrophication until hypoxic stress reverses this trend (Cederwall \& Elmgren 1990).

The strong seasonality of macrobenthic biomass in the middle Bay may also be partially driven by hypoxia. High summer mortality in sediments below the pycnocline destroys the large spring recruitment of opportunistic species in early spring, and this is followed by limited recolonization upon return to normoxia in autumn (Holland et al. 1987). Episodic winddriven lateral oscillations in the Bay's pycnocline cause hypoxic deep channel water to well up onto adjacent 
shoals (Malone et al. 1986, Sanford et al. 1990), thereby degrading the shallow-water macrobenthic communities in these otherwise normoxic habitats (Breitburg 1990, Hagy 2002). In addition, infaunal biomass tends to decline with incipient hypoxia (Holland et al. 1987), reflecting increased vulnerability to predation for these new recruits (Pihl et al. 1992). Even in shallow normoxic regions, common midsummer declines in benthos appear due to intensified predation by benthivorous nekton excluded from adjacent deep hypoxic waters (Kemp \& Boynton 1981).

\section{Zooplankton responses to nutrients}

In contrast to benthic invertebrates, there is little evidence of zooplankton community responses to eutrophication in Chesapeake Bay. The Bay's 2 dominant copepod species Acartia tonsa and Eurytemora affinis play pivotal roles in transferring phytoplankton production to fish (Baird \& Ulanowicz 1989). These copepods are consumed directly by bay anchovy, the estuary's most abundant fish (Rilling \& Houde 1999), and by juvenile menhaden, white perch, and other forage fish (e.g. North \& Houde 2003). Copepods also experience significant mortality due to predation by gelatinous consumers, particularly the planktivorous ctenophore Mnemiopsis leidyi (Feigenbaum \& Kelly 1984). Feeding and bioenergetic studies (Heinle 1966, Heinle et al. 1977) suggest that zooplankton growth in the Bay is generally not limited by food (White \& Roman 1992). Although copepod biomass may be stimulated by nutrient additions in mesocosms (Bundy et al. 2003), such responses generally do not occur in the presence of planktivorous predators at natural abundances (Breitburg et al. 1999).

Zooplankton abundance and production in Chesapeake Bay and other estuaries may, however, also be affected by eutrophication-induced changes in copepod habitats. For example, increases in bottom-water hypoxia may reduce adult survival and egg hatching in Acartia tonsa and Oithona colcarva (Roman et al. 1993). Indeed, significantly reduced copepod abundances have been noted in hypoxic waters of the Bay and other estuaries (e.g. Caumette et al. 1983, Keister et al. 2000). Although inverse correlations between zooplankton abundance and nutrient or chl-a concentrations have been reported for highly eutrophic Bay tributaries (Park \& Marshall 2000), such relationships are not evident for most of the Bay (Kimmel \& Roman 2004) or for other shallow estuaries (Lawrence et al. 2004). Hypoxia is a poor predictor of Eurytemora affinis abundance, but these copepods are strongly related to interannual variations in the size of oligohaline and turbid habitats (Roman et al. 2001, Kimmel \& Roman
2004) in the upper Bay, where food (detritus and particle-attached bacteria, Crump et al. 1998) is abundant while salinity and temperature conditions best suit the physiological needs of these animals (Bradley 1975).

Variations in freshwater inflow to the Bay can also alter the balance between bottom-up and top-down controls on zooplankton (Purcell \& Decker 2005). Not only does high flow deliver more nutrients and extend the habitat of Eurytemora affinis, it also reduces the distribution and abundance of the medusa Chrysaora quinquecirrha (Purcell et al. 1999), which feeds heavily on Mnemiopsis leidyi (Purcell \& Cowan 1995). Under the low flow conditions of 1995, for example, elevated salinity throughout the Bay promoted large summer populations of C. quinquecirrha, which controlled the ctenophores, releasing copepods from predation and allowing them to increase (Fig. 13). In contrast, high flow conditions in 1996 stimulated spring abundance of copepods (primarily E. affinis) by increasing oligohaline habitat (and perhaps stimulating algal growth); however, low salinity also suppressed summer populations of C. quinquecirrha, thereby allowing $M$. leidyi to flourish and graze down copepods (Fig. 13). Such 'trophic cascades' involving copepods and jellyfish might also be initiated by changes in fishing pressure, as in the Black Sea, where concurrent overfishing and introduction of non-native M. leidyi may have created an unbalanced food web (Daskalov 2002, Gucu 2002).

It has been suggested that eutrophication-induced changes in phytoplankton community structure and $\mathrm{O}_{2}$ conditions of estuaries might lead to shifts in planktonic food webs, favoring pathways dominated by bacteria and gelatinous predators (e.g. Egge \& Aksnes 1992, Purcell et al. 2001, Turner 2001). Although bacterioplankton abundance is high in Chesapeake Bay waters (e.g. Jonas 1997), the ratio of bacterioplankton to phytoplankton production is lower than expected from relationships in more oligotrophic systems (e.g. Ducklow \& Shiah 1992). Statistical relationships between hypoxia and jellyfish abundance, reported at interannual and system-level scales for other eutrophic coastal regions, are limited to smaller geographic and temporal scales within the Bay (Purcell et al. 2001).

\section{Loss of oyster beds and benthic filtration}

Extensive reefs of the eastern oyster Crassostrea virginica built up along the flanks of Chesapeake Bay and its tributaries during and after the Holocene transgression. Because the Bay bottom is composed predominantly of fine particles, oysters created a unique hardsubstrate habitat for diverse invertebrate and fish populations (Coen et al. 1999). Oysters supported a valuable fishery, with substantial landings from the 

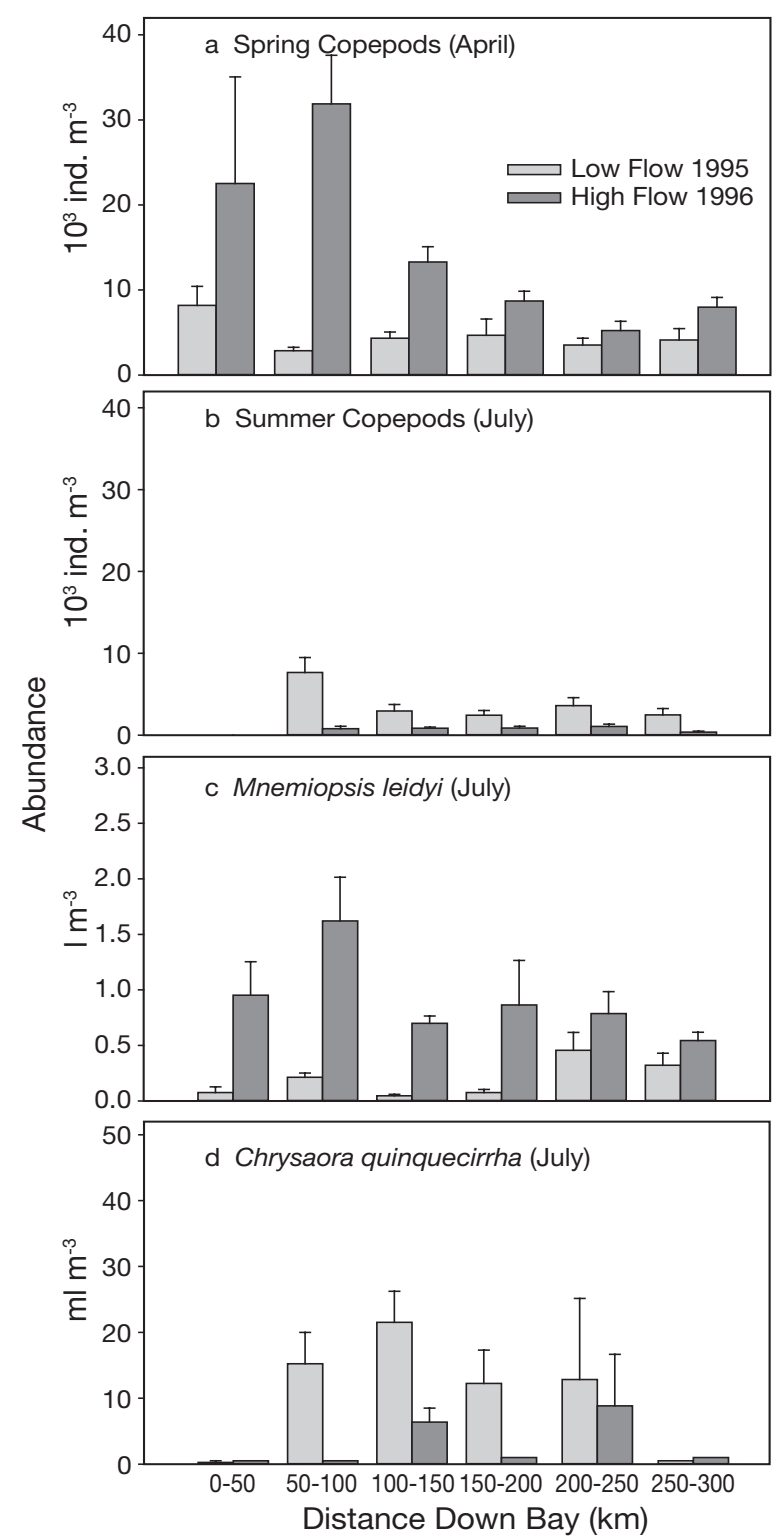

Fig. 13. Variations in abundance (number of individuals or biovolume) of key plankton consumers along a longitudinal transect from upper to lower main-stem Chesapeake Bay for relatively low flow year (light shaded bars, 1995) and relatively high flow year (dark shaded bars, 1996). Copepods are mostly Acartia tonsa and Eurytemora affinis; the ctenophore Mnemiopsis leidyi consumes mostly copepods and the medusa Chrysaora quinquecirrha consumes copepods and ctenophores; data are binned into 6 regions $(0-50,50-100$, $100-150,150-200,200-250,250-300 \mathrm{~km}$ ) along length of Bay, with numbers of observations in each bin ranging from 3 to 18 (M. Roman et al. unpubl.)

1880s to the early 1900s (Fig. 14). Although Bay oyster growth may have been initially stimulated by anthropogenic nutrient enrichment (Kirby \& Miller 2005), these levels of exploitation proved unsustainable because of excessive removal of adult oysters and their shell substrate (Kennedy \& Breisch 1981). Loss of verti- cal relief made remaining shell more susceptible to siltation, compounding population decline (Smith et al. 2003b). This fishery-related decline was exacerbated in the 1950s by outbreaks of 2 major parasitic diseases, MSX (Haplosporidium nelsoni) and 'Dermo' (Perkinsus marinus) (Rothschild et al. 1994). Today, oyster abundance in the Bay has been reduced to $\sim 1 \%$ of 19 th century levels.

Suspension feeding by benthic bivalves, such as oysters, tends to cause a shift in the balance from planktonic to benthic production by reducing concentrations of phytoplankton and other suspended particulates, thereby increasing light levels reaching the sediment surface (e.g. Cohen et al. 1984, Newell \& Koch 2004). The Bay's 19th century oyster population filtered (during summer months) a water volume equivalent to that of the upper and middle Bay in $\sim 3.6 \mathrm{~d}$; however, oyster declines have increased this filtration time to several hundred days at present (Fig. 14 inset, Newell 1988). Although this calculation involves many simplifying assumptions, it illustrates the magnitude of potential ecosystem effects associated with loss of oysters (e.g. Gerritsen et al. 1994). Similar calculations for other coastal systems also suggest large potential impacts of benthic filter-feeding invertebrates (Cloern 1982, Loo \& Rosenberg 1989). Benthic filter feeders can, thus, substantially alter trophic dynamics in planktonic and benthic communities (e.g. Ulanowicz \& Tuttle 1992, Strayer et al. 1999).

Benthic filtration can also affect nutrient cycling processes. Whereas intense benthic filtration associated with commercial culture can stimulate nutrient recycling (e.g. Souchu et al. 2001) and growth of benthic macroalgae (e.g. Rafaelli et al. 1998), experiments in the Bay suggest that natural oyster reefs may actually

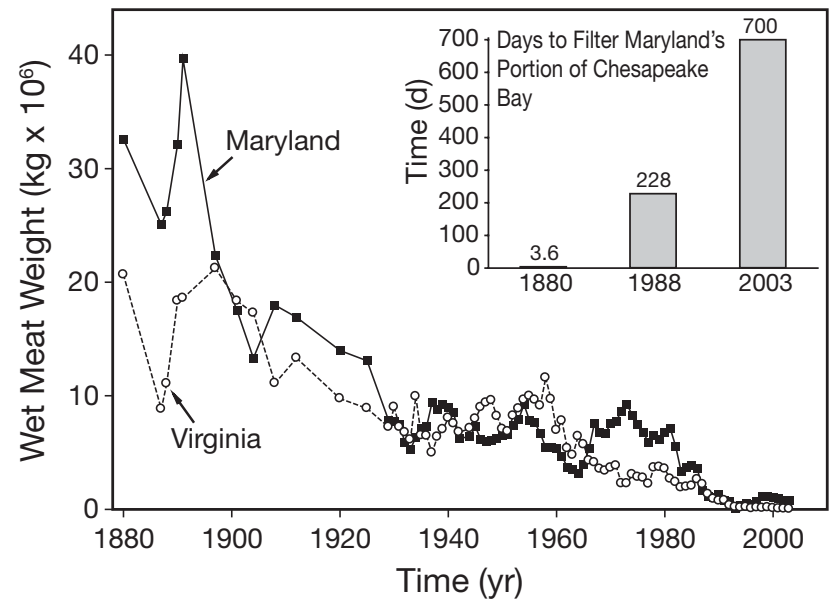

Fig. 14. Historical record of harvest of eastern oyster (Crassostria virginica) from Chesapeake Bay. Inset shows calculated changes in time required for oyster population in each year to filter a volume of water equal to that in the Bay north of $\sim 38^{\circ} \mathrm{N}$ latitude (adapted from Newell 1988) 
reduce the efficiency by which nutrients are recycled to phytoplankton. The eastern oyster maintains high clearance rates that are relatively independent of food concentration, resulting in the production of copious particulate $\mathrm{N}$ and $\mathrm{P}$ as pseudofeces (Newell et al. 2005). Most of this material is deposited initially in shallow areas, where it supports enhanced production of deposit-feeding animals and benthic microalgae (Newell et al. 2005). Increased $\mathrm{NH}_{4}{ }^{+}$production in oyster biodeposits that are degraded in shallow oxygenated sediments may also stimulate $\mathrm{N}_{2}$ loss via coupled nitrification-denitrification (Newell et al. 2002). To the extent that oyster biodeposits are retained in estuarine shoals, their production helps to reduce delivery of planktonic organic matter to the deep channel where it fuels hypoxia. The demise of oysters in the Bay has, however, rendered these processes inoperative.

\section{Fish and fisheries responses}

Chesapeake Bay is a productive fisheries ecosystem, with commercial landings that exceeded 225000 metric tons (196 kg ha ${ }^{-1}$ ) until the mid-1990s, when they declined to about 170000 tons (Houde et al. 1999). Eutrophication and associated hypoxia may have altered community structure and productivity of fish and invertebrates that sustain Bay fisheries (Breitburg 2002). Changes in fish populations and fisheries harvest that occurred during the past 2 centuries are, however, also tied to many factors, including shifts in fisheries preferences, fishing effort, markets, loss of habitats, declining water quality, and variable climate/weather.

Conceptually, it has been proposed (Caddy 1993, 2000) that eutrophication effects on fish communities follow a sequence of 3 stages: (1) nutrient-enhanced production of demersal and pelagic species (more food), (2) decline of demersal fish but continued increase in pelagic fish species (benthic habitat loss), and (3) a general decline in total fish production under conditions of broadly deteriorating water and habitat quality. Based on landings, this sequence has been, in part, observed in Chesapeake Bay. Fisheries landings are now dominated by the pelagic species Atlantic menhaden, with catches $>150000$ tons during the 1980s and early 1990s. It is probable that long-term increases in overall production of menhaden (Luo et al. 2001) and other Bay fisheries have been stimulated by increased nutrient loading, as in other ecosystems (Nixon \& Buckley 2002). Although lesions on fish, HAB-induced fish kills, and fish/crab mortalities from hypoxic events appear to be increasing, there is only limited evidence that eutrophication has pushed the Bay ecosystem into Caddy's third stage.
The dramatic impact of increased fishing pressure makes it difficult to detect any effects of eutrophication on the Bay's fish populations. For example, as with the precipitous decline in eastern oyster Crassostrea virginica harvest (Fig. 14), recent declines in blue crab landings since 1990 likely resulted primarily from excessive fishing (CBC 2003), not eutrophication. Fishing mortality and climatic factors led to the decline and failed recruitments of striped bass Morone saxatilis, and subsequent recovery has occurred by managing harvest (Richards \& Rago 1999). Some species such as sturgeons, extirpated nearly a century ago by fishing and habitat loss, probably can no longer reproduce or rear young in the eutrophic Bay due to lack of summer habitat with $\mathrm{O}_{2}$ and temperature levels needed for growth and survival (Niklitschek 2001). Even for dystrophic ecosystems such as the Black Sea and Seto Inland Sea, it has been suggested that excessive fishing contributed substantially to the destabilization of food chains and the shifts toward dominance by gelatinous planktonic predators (Daskalov 2002, Gucu 2002, Nagai 2003).

In general, increases in the ratio of landings of pelagic to demersal fish species (P:D) have been associated with eutrophication (de Leiva Moreno et al. 2000). In Chesapeake Bay, this ratio increased from 1.90 in the 1960 s to 2.66 in the 1990s (Fig. 15). Com-
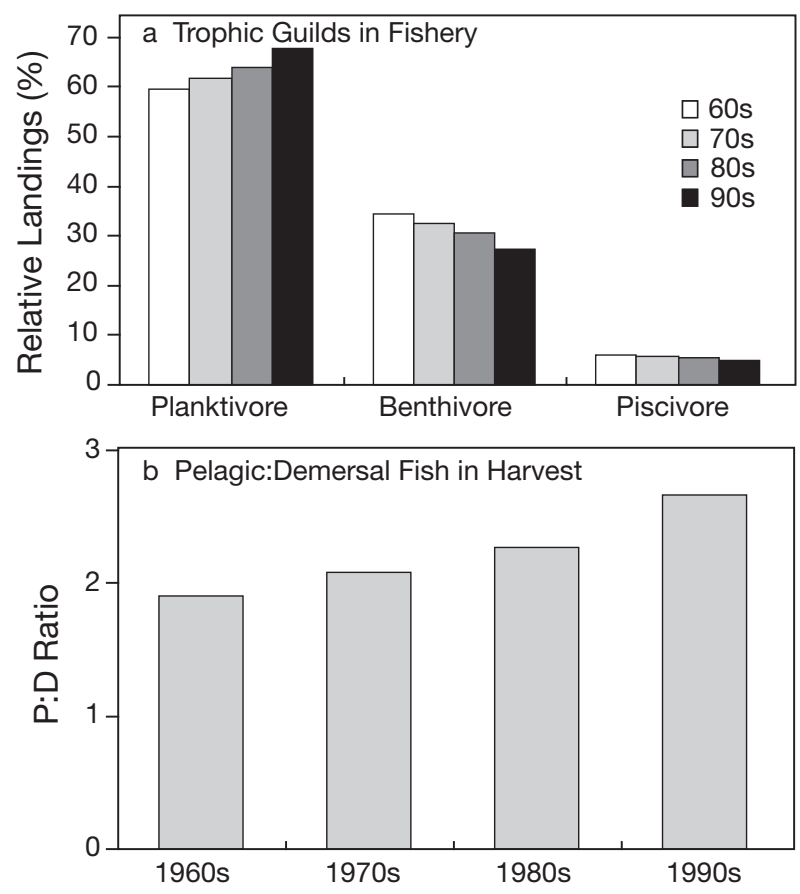

Fig. 15. Decadal changes in relative landings (\% of total weight) for fish and invertebrate species harvested in Chesapeake Bay from 1960s to 1990s, (a) organized into 3 feeding guilds (planktivores, bentivores, piscivores) and (b) organized as the ratio of planktivores:benthivores (P:D). Data adapted from Web site (www.noaa.chesapeakebay.net) 
mercial landings of demersal benthivores declined from $34.4 \%$ to $27.3 \%$ of the catch, with concomitant increases in relative landings of pelagic species. The largest shift was the progressive increase in pelagic Atlantic menhaden landings $(\sim 38 \%$ in the 1960 s to $\sim 67 \%$ in the 1990s). Declines in demersal blue crab and oyster landings also contributed to these trends. Whereas the increase in P:D may be related to parallel increases in nutrient inputs, phytoplankton biomass, and hypoxia (e.g. Figs. 4, 7 \& 8), shifts in coastal fishing patterns and markets were also factors. In addition, the ratio of commercial fishery yield (Houde et al. 1999) to net primary production (PP, Harding et al. 2002) suggests declining trophic efficiency in the Bay. Fishery yields were $\sim 2.20 \mathrm{~g} \mathrm{C} \mathrm{m}^{-2} \mathrm{yr}^{-1}(0.54 \%$ of PP) in the 1980s compared to $\sim 1.85 \mathrm{~g} \mathrm{C} \mathrm{m}^{-2} \mathrm{yr}^{-1}(0.45 \%)$ for the mid-1990s. The absence of clear evidence of declines in fish productivity does not necessarily indicate that there have been no effects of eutrophication on Bay fisheries. As indicated for the Black Sea, detrimental effects of eutrophication may not be fully manifested until a combination of excessive fishing activity, unusual climate regimes, introductions of alien species, and nutrient loading overwhelm the ecosystem's resilience.

\section{SCIENCE AND NUTRIENT-REDUCTION STRATEGIES}

\section{Nutrient limitation for primary production}

A question central to the application of scientific understanding to eutrophication management is the relative importance of $\mathrm{N}$ and $\mathrm{P}$ as nutrients limiting phytoplankton primary production (e.g. Likens 1972). Whereas estuarine ecosystem responses to nutrient enrichment are varied and complex, most start with stimulation of algal (primarily phytoplankton) growth. In developing a nutrient management strategy, it is therefore crucial to understand how nutrients limit algal growth in time and space (Graneli et al. 1990). Lake phytoplankton are generally P-limited (Schindler 1981), while marine phytoplankton are more often Nlimited (Ryther \& Dunstan (1971). P limitation may also dominate in coastal ecosystems where water exchange rates exceed $P$ recycling rates (e.g. Smith 1984). Nutrient ( $\mathrm{N}$ or $\mathrm{P}$ ) limitation in estuaries tends to vary with season (e.g. D'Elia et al. 1986, Paasche \& Erga 1988) and salinity regime (Caraco et al. 1987).

The relative importance of nutrients and light in limiting phytoplankton in the Bay exhibits well-defined seasonal and regional variations (Fig. 16). (We define 'light limitation' as ambient conditions where phytoplankton growth is controlled by insufficient light, thereby precluding growth responses to nutrient addi-

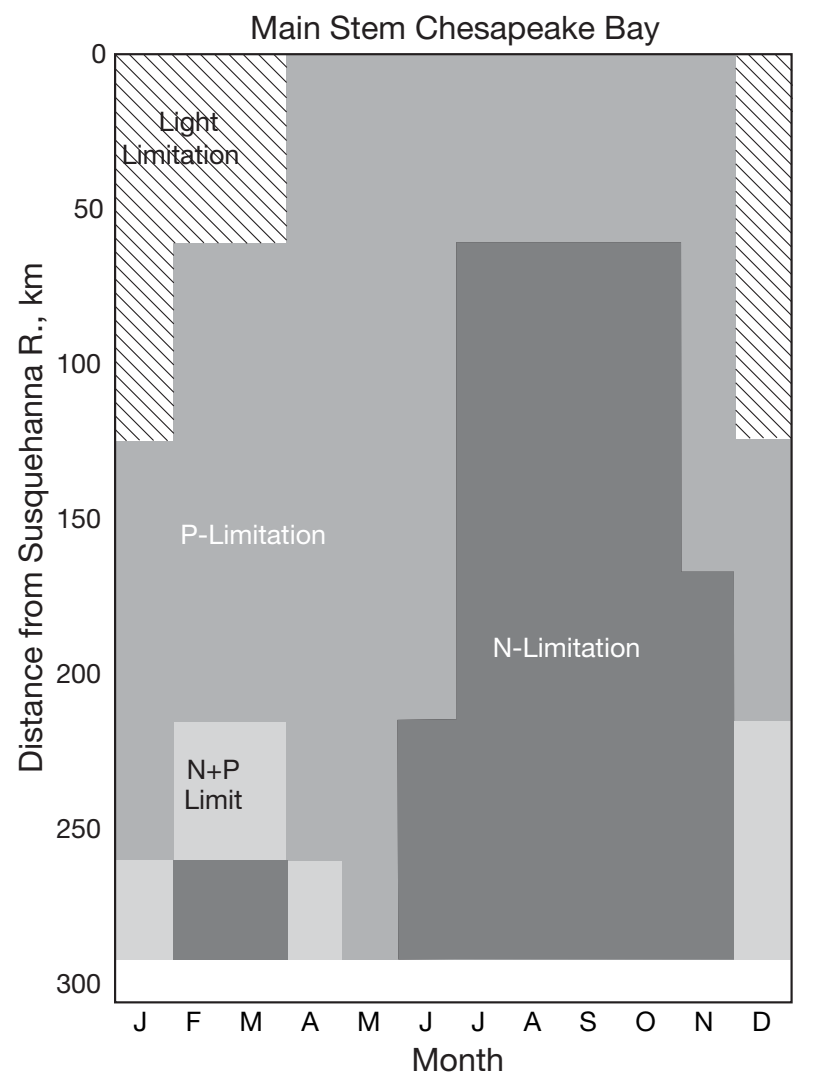

Fig. 16. Seasonal and regional variations in nitrogen, phosphorous or light limitation for phytoplankton growth synthesized from bioassay experiments conducted in main stem of Chesapeake Bay between 1992 and 2002 (Fisher et al. 1992, 1999, 2003). N- and P-limitations were defined as increases in phytoplankton productivity (PP) and biomass (PB) with $\mathrm{N}$ and $\mathrm{P}$, respectively, additions to experimental containers; N+Plimitation was defined as increases in PP and PB only with simultaneous additions of $\mathrm{N}$ plus $\mathrm{P}$. 'Light-limitation' was defined by the lack of significant responses to any combination of $\mathrm{N}$ and/or $\mathrm{P}$ addition, combined with a uniform response of increased PP and PB during incubations for controls and all treatments relative to initial ambient conditions

tion.) Such conditions are common in the vertically mixed upper Bay waters during winter when salinity is low, water is turbid, and nutrients are replete. P limitation occurs primarily in spring (April-May), when $\mathrm{DIN}: \mathrm{PO}_{4}$ ratios of inflowing river exceed $60: 1$, and other resources or conditions are not limiting. For brief periods in late autumn, P limitation is also evident in the upper and middle Bay. $\mathrm{N}$ limitation is common throughout the Bay in summer and early autumn when DIN is depleted from surface waters, while rates of $\mathrm{PO}_{4}$ release from anoxic sediments are high (Fig. 9) and nutrient inputs from point sources with low DIN:PO ratios (<10:1) are more important (Fisher et al. 1992). In the lower Bay, $\mathrm{N}$ and $\mathrm{P}$ commonly exhibit colimitation when both concentrations are low (DIN $<0.5 \mu \mathrm{mol}^{-1}$; $\mathrm{PO}_{4}<0.1 \mu \mathrm{mol} \mathrm{l}^{-1}$ ). 
These strong seasonal and regional patterns have important management implications for controlling eutrophication in Chesapeake Bay (D'Elia et al. 2003). Reductions in both $\mathrm{N}$ and $\mathrm{P}$ from rivers and point sources would be required to reduce Bay phytoplankton biomass consistently throughout the year for the whole Bay (Fig. 16). It is tempting to suggest efficient nutrient management may be achieved by varying controls on $\mathrm{N}$ and $\mathrm{P}$ inputs seasonally and regionally; however, such approaches may have limited utility. For example, the relatively long but variable residence time of Bay water makes it difficult to time changes in nutrient inputs to ecological responses in specific regions and seasons. As noted elsewhere, controlling only $\mathrm{P}$ in the upper Bay, where it is limiting, is likely to cause excess concentrations of the uncontrolled nutrient $(\mathrm{N})$, which would be transported seaward to stimulate downstream algal growth (Paerl et al. 2004).

\section{Examples of ecosystem responses to reduced inputs of $\mathrm{N}$ and/or $\mathrm{P}$}

Although reductions in both $\mathrm{N}$ and $\mathrm{P}$ inputs will be required to effect substantial reversal of eutrophication throughout the Bay, partial nutrient reduction in tributaries has elicited significant ecological benefits. Two case studies from Chesapeake Bay tributaries, the Potomac and Patuxent River estuaries, serve to illustrate ecosystem responses to reductions in $\mathrm{P}$ and $\mathrm{N}$ inputs. In both systems, pointsource effluents comprise a large fraction of the total nutrient loading.

In the Potomac River estuary, improved sewage treatment in Washington, DC produced a sharp reduction in pointsource P (and, to a lesser extent, N) loading beginning in the early 1970s (Jaworski 1990). This was followed by substantial changes in ecosystem characteristics within the tidal freshwater region of the estuary. Rapid responses included decreased algal biomass, higher water column $\mathrm{O}_{2}$ levels, and increased water clarity, while submersed vascular plants exhibited delayed but subsequently extensive recolonization of shoal areas beginning in 1983 (Fig. 17). Observed increases in $\mathrm{O}_{2}$ are probably attributable to a combination of decreases in $\mathrm{P}$ and organic loading (not shown) from sewage treatment facilities. The latter would account for direct reduction in $\mathrm{O}_{2}$ demand, and the for-
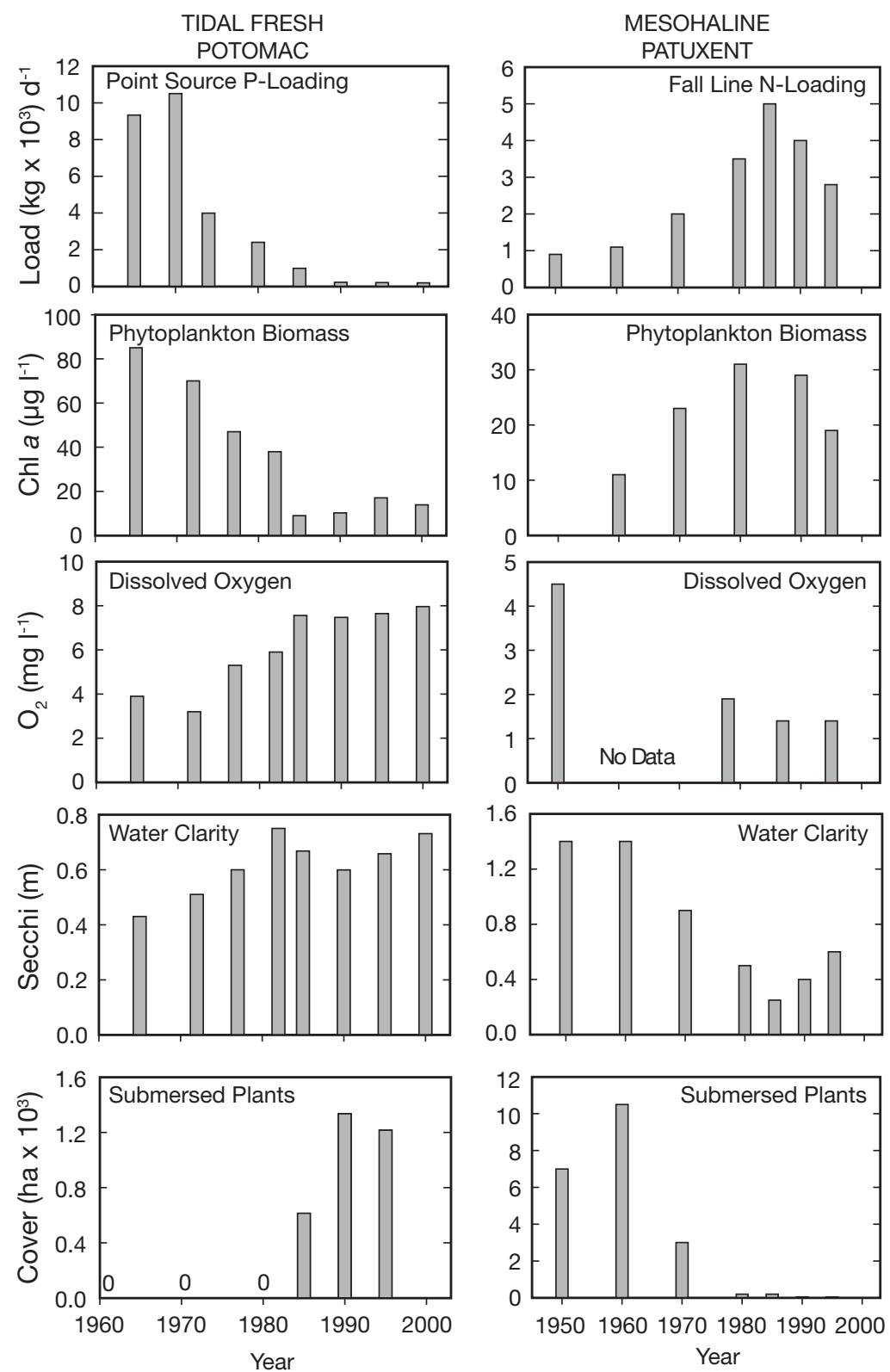

Fig. 17. Time-series plots of nutrient loads, phytoplankton biomass, dissolved $\mathrm{O}_{2}$, water clarity and submersed vascular plant biomass in tidal fresh portion of Potomac River estuary and mesohaline portion of Patuxent River estuary. Data are averaged for 5 or 10 yr intervals. Phytoplankton chl-a concentrations are from surface waters at both locations, dissolved $\mathrm{O}_{2}$ concentrations are water column averages for Potomac and bottom layer averages for Patuxent. Water clarity was measured with a Secchi disk at both sites. Potomac data sources were as follows: nutrient loads from N. Jaworski (pers. comm.) and Chesapeake Bay Program (CBP, www.chesapeakebay.net), plankton biomass, dissolved $\mathrm{O}_{2}$ and water clarity from N. Jaworski (pers. comm.) and CBP and submersed plants from Carter \& Rybicki (1986) and CBP. Patuxent data sources were: nutrient loads from D'Elia et al. (2003), plankton biomass, $\mathrm{O}_{2}$, water clarity and submersed plants from Heinle et al. (1980), Stankelis et al. (2003) and CBP 
mer would result in reduced algal biomass (Fig. 17) retention and decomposition within this estuarine region. The recovery of submersed plants, which was their first appearance since their demise in the 1930s (Carter \& Rybicki 1986), was attributed to the improved water clarity (Carter \& Rybicki 1990, Carter et al. 1994). Resurgent submersed plant beds were initially (1980) dominated by the non-native species Hydrilla verticillata, but by 1985 approx. 14 native plant species were observed in the region (Carter \& Rybicki 1986). Increased benthic suspension feeding associated with a contemporaneous invasion of the non-native clam Corbicula fluminea probably contributed to initial recovery of this region of the Potomac. By 1982, however, density of these clams had declined to $10 \%$ of their peak abundance without discernible reductions in water quality (Cohen et al. 1984, Phelps 1994).

During the same general time period, changes in nutrient loading to the Patuxent River estuary produced a more complex pattern (Fig. 17). Inputs of $\mathrm{N}$ increased markedly between 1950 and 1985 and, with the application of advanced wastewater treatment, started a decline in the early 1990s that has continued to the present. P inputs decreased abruptly in the late 1980s with sewage treatment improvements and the banning of $\mathrm{PO}_{4}$ from detergents (D'Elia et al. 2003). Biomass of phytoplankton followed trends in nutrient loading closely, while water clarity and dissolved $\mathrm{O}_{2}$ in deep waters declined with increasing $\mathrm{N}$ loading but have thus far shown little sign of recovery with the recent reduced loading (Fig. 17). The decline in submersed plants began in the late 1960s, with most of the estuary becoming devoid of these plants by the mid-1970s (Stankelis et al. 2003). Efforts to restore submersed plants via both planting of shoots and seeds have failed to produce stands of plants that persist for more than a year. In general, shoots planted in spring or fall (or areas seeded in fall) emerged and grew well during cool periods $\left(<20^{\circ} \mathrm{C}\right)$ but became heavily covered by epiphytic algae in early summer and died by the end of that summer or by the middle of the next (Stankelis et al. 2003). Evidently, nutrient load reductions are still insufficient for the successful expansion of submersed plants in the lower Patuxent River estuary.

These examples illustrate the propensity of this estuarine ecosystem for recovery from eutrophication effects. They also reveal potential weaknesses of single vs. dual nutrient reduction strategies. In the Potomac, for example, ecosystem responses to P removal have been confined to the tidal fresh region, and, as observed elsewhere (Paerl et al. 2004), water quality conditions have not improved in the lower estuary as unassimilated DIN has been transported seaward to stimulate algal growth in the $\mathrm{N}$-limited region.
Removal of $\mathrm{N}$ and $\mathrm{P}$ in the Patuxent has resulted in improved water quality throughout the estuary, although responses of submersed plants and bottom $\mathrm{O}_{2}$ have been limited to date. Even in the Potomac's tidal fresh region, changes in concentrations of chl-a and $\mathrm{PO}_{4}$ suggest a hysteretic pattern, where the same chl-a levels are associated with lower values of $\mathrm{PO}_{4}$ during the recovery period (1990s) compared to the degradation (1970s) period (Jones 2000). Nutrient management strategies should be developed with awareness of the potential for such non-linear feedback effects (e.g. Yamamoto 2003).

\section{Strategies for nutrient reductions}

Results of scientific research have contributed to a political and public awareness and commitment to reverse eutrophication in the Chesapeake Bay (Malone et al. 1993). Documentation of improved water quality in the tidal Potomac River following upgrading of wastewater treatment led to growing awareness of eutrophication problems and the prospects for correcting them. By the early 1980s, however, research results were suggesting that eutrophication was a far more pervasive problem throughout the Bay (Boesch et al. 2001). This perspective was translated into a series of agreements - involving all political jurisdictions within the watershed - to reduce inputs of both $\mathrm{N}$ and $\mathrm{P}$ from point and non-point sources (D'Elia et al. 2003). Researchers and managers collaborated in developing detailed nutrient budgets and water quality models to produce management strategies. Public commitments to reducing eutrophication were recently codified in the ambitious Chesapeake 2000 (C2K) agreement (www.chesapeakebay.net), which calls for reductions of $48 \%$ and $53 \%$ for total $\mathrm{N}$ and $\mathrm{P}$ inputs, respectively (based on 1985 levels).

An important component of the $\mathrm{C} 2 \mathrm{~K}$ agreement is a plan for restoring 3 major Bay habitats-seagrass beds, oyster reefs, and tidal marshes. Although largescale recovery of seagrass will ultimately require substantial water quality improvement (e.g. Dennison et al. 1993, Kemp et al. 2004), this process can be accelerated via regional strategies: (1) in the lower Bay by direct dispersal of plant seeds collected from existing Zostera marina beds (Harwell \& Orth 2002), (2) in the upper Bay by protection of existing small plant beds (in tertiary tributaries) that serve as seed and fragment sources (e.g. Rybicki et al. 2001), and (3) in the middle Bay by using existing but ephemeral Ruppia maritima beds as 'nursery areas' for transplanting more stable perennial species. Initial efforts to increase eastern oyster biomass by 10-fold (www.oysterrecovery.org) have produced modest success in isolated areas, but 
Bay-wide restoration will require solving problems of diseases and shortages of seed stocks and hard substrates (NRC 2004). Restoration of the Bay's tidal marshes faces the basic problem of insufficient inputs of natural sediment to keep pace with sea-level rise. Recent efforts to restore marshes using channeldredging spoils have generated new techniques to oxidize and dewater sediments. In any case, even small progress in the restoration of these habitats could yield substantial benefits toward recovery from eutrophication because key ecological processes (e.g. nutrient assimilation, particle trapping, filter feeding, denitrification) are enhanced through inherent biological positive-feedback mechanisms.

\section{SYNTHESIS}

Symptoms of ecological response to eutrophication have been manifested at a range of time scales in Chesapeake Bay. Initial signs of organic enrichment are evident in $200 \mathrm{yr}$ old sediment strata, while evidence of increased algal production and decreased water clarity appear in 100 yr old sediment layers. Severe hypoxia and loss of submersed plants were first evident only 4 to 5 decades ago. These changes in shallow habitats, combined with hypoxiainduced loss of the deep benthic habitats, probably contributed to a gradual increase in the relative importance of pelagic (compared to demersal) food chains and declines in associated trophic efficiency (e.g. fishery harvest per unit primary production) over the last several decades. Because scientific interest in these ecological changes tends to lag behind their occurrence, historical knowledge of responses to eutrophication depends largely on fairly imprecise interpretation of biogeochemical indices in sediment strata and on retrospective analysis of data collected for other purposes.

A rich but indirect body of evidence suggests that Bay responses to nutrient enrichment are complicated by a range of non-linear ecological feedback mechanisms (Fig. 18; also see Bonsdorff et al. 1997). For example, enhanced particle trapping and sediment binding associated with benthic plants (seagrass, microalgae) help to maintain relatively clear water columns, allowing more light to support more benthic photosynthesis. As the Bay 'degrades' and becomes more turbid with enrichment, however, these benthic autotrophic communities decline, allowing more resuspension, decreased light, and so on. Similarly, nutrient-enhanced phytoplankton growth and sinking support increased benthic respiration and severe anoxia, which causes more efficient benthic recycling of $\mathrm{N}$ (inhibition of nitrification-denitrification) and $\mathrm{P}$ (increased solubility of $\mathrm{PO}_{4}$ ) to support further production of phytoplankton (including $\mathrm{HABs}$ ) in overlying water.

Although the positive-feedback nature of these interactions means that they will tend to reinforce and accelerate the eutrophication process, it also means that they will reinforce the 'restoration' process by enhancing water quality improvements once they are initiated (Fig. 18). The relatively rapid recoveries of some water quality variables with reduced nutrient

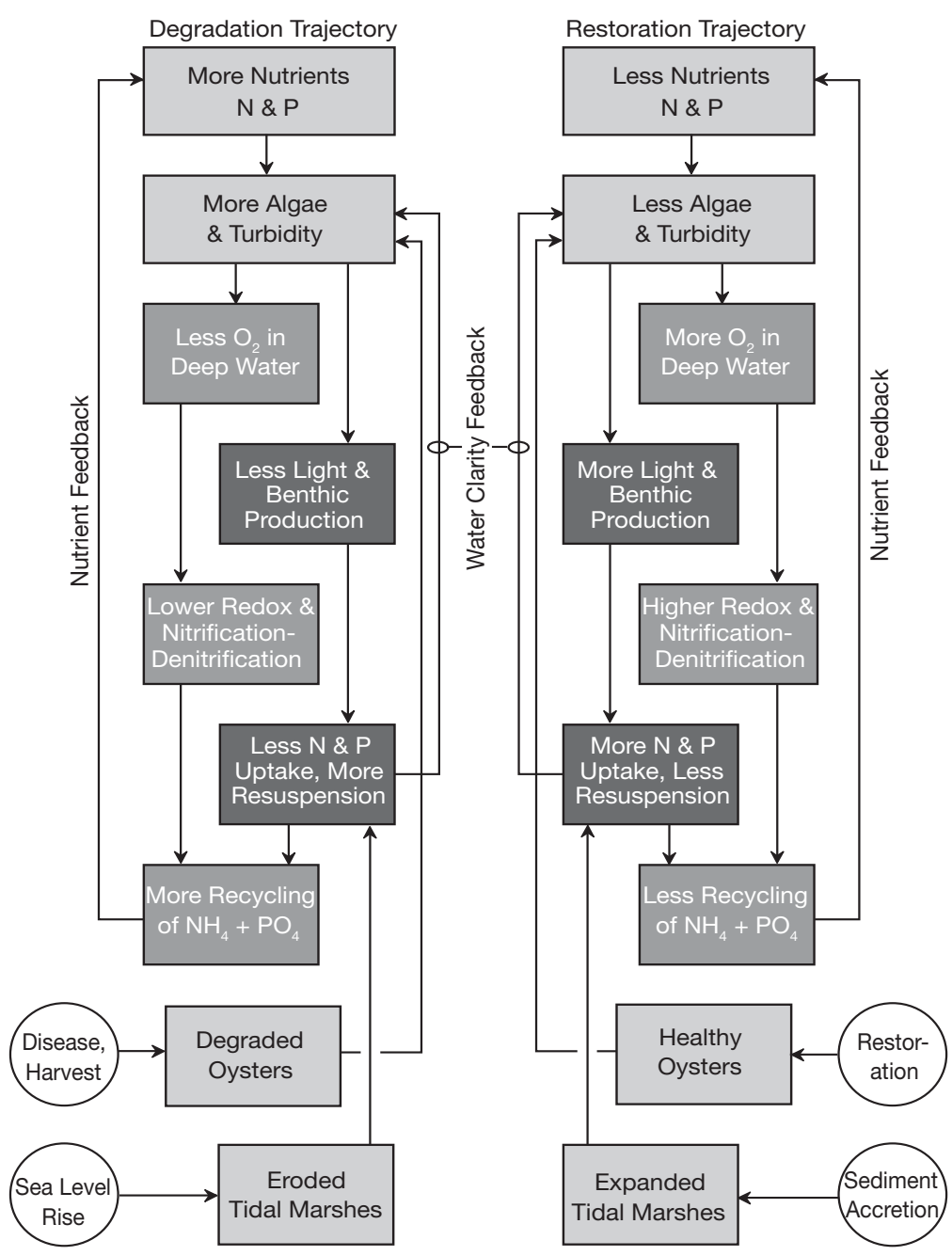

Fig. 18. Logic flow diagram illustrating how nutrient addition affects algal biomass (light gray boxes), which affects both bottom-water oxygen and nutrient recycling (medium gray boxes) as well as water clarity and benthic primary production (dark gray boxes), and how positive feedback mechanisms (related both to nutrient levels and to water clarity) reinforce this eutrophication cascade regardless of the trajectory. Also illustrated is how the health of oyster reefs and tidal marshes (light gray boxes) affects these interactions. Along a 'degradation trajectory' these interactions reinforce the decline in water quality and habitat condition; however, along a 'restoration trajectory' they reinforce the improvement of water and habitat quality 
loading in the Potomac and Patuxent tributary systems (Fig. 17) may reflect these positive-feedback processes, while hysteresis is evident in the delayed recovery of submersed plant beds. Water filtration from oyster reefs provides a negative-feedback control on eutrophication by reducing plankton biomass and increasing water clarity (Fig. 18). Development of many of the Bay's tidal marshes may have actually been promoted by sediment and nutrient loading from cultural eutrophication. Once established, however, the ability of these marshes to trap, assimilate, and remove nutrients (Fig. 18) has made them effective buffers, providing a negative-feedback control on further nutrient inputs from watershed to estuary. Unfortunately, however, this control is now being lost to sea-level rise.

There remain many compelling and relevant scientific questions pertaining to responses of Chesapeake Bay and other estuaries to nutrient loading. Details of how interactions among organisms and biogeochemical processes regulate dynamic ecological responses to nutrient inputs are unresolved. Evidence for hysteresis in the recovery process suggests the existence of complex mechanisms that are not fully described but that may be important for managing estuarine resources (e.g. Jeppesen et al. 1998). Hypothesized eutrophication-induced changes in trophic structure and shifts between benthic and pelagic food chains need to be understood better, particularly as they affect the efficiency at which photosynthesis is converted into fisheries production. Future research on coastal eutrophication should be designed to promote both applied and basic scientific objectives, serving to deepen our understanding of estuarine ecosystem function and to develop prudent and effective strategies for managing valuable coastal resources.

Acknowledgements. We are indebted to many individuals who contributed discussions, analyses, and technical support for this paper and the research upon which it is based. These include R. Batiuk, M. Brooks, J. Caffrey, J. Davis, B. Dennison, R. Lacouture, C. Madden, M. Mallonee, L. Murray, K. Moore, B. Orth, M. Owens, L. Staver, and J. Testa. Support for the work was provided over many years by numerous funding agencies, including US Environmental Protection Agency, NOAA Maryland Sea Grant College, NOAA Coastal Ocean Program, National Science Foundation, Maryland Department of Environment, and Maryland Department of Natural Resources. This is contribution number 3899 from the University of Maryland Center for Environmental Science.

\section{LITERATURE CITED}

Adelson JM, Helz GR, Miller CV (2001) Reconstructing the rise of recent coastal anoxia: molybdenum in Chesapeake Bay sediments. Geochim Cosmochim Acta 65:237-252

Andersen L, Rydberg L (1988) Trends in nutrient and oxygen conditions within the Kattegat: effects of local nutrient supply. Estuar Coast Shelf Sci 26:559-579
Anderson DA, Glibert PM, Burkholder JM (2002) Harmful algal blooms and eutrophication: Nutrient sources, composition and consequences. Estuaries 25:562-584

Baird D, Ulanowicz RE (1989) The seasonal dynamics of the Chesapeake Bay ecosystem. Ecol Monogr 59:329-364

Bayley S, Stotts VD, Springer PF, Steenis J (1978) Changes in submerged aquatic macrophyte populations at the head of Chesapeake Bay, 1958-1975. Estuaries 1:73-84

Berg GM, Glibert PM, Lomas MW, Burford M (1997) Organic nitrogen uptake and growth by the Chrysophyte Aureococcus anophagefferens during a brown tide event. Mar Biol 129:377-387

Billen G, Lancelot C, Meybeck M (1991) N, P, and Si retention along the aquatic continuum from land to ocean. In: Mantoua RFC, Martin JM, Wollast R (eds) Ocean margin processes in global change. Wiley, New York, p 19-44

Boesch DF, Rosenberg R (1981) Response to stress in marine benthic communities. In: Barrett GW, Rosenberg R (eds) Stress effects on natural ecosystems. Wiley, New York, p 179-200

Boesch DF, Brinsfield RB, Magnien RE (2001) Chesapeake Bay eutrophication: scientific understanding, ecosystem restoration, and challenges for agriculture. J Environ Qual 30:303-320

Boicourt WC (1992) Influences of circulation processes on dissolved oxygen in the Chesapeake Bay. In: Smith DE, Leffler M, Mackiernan G (eds) Oxygen dynamics in the Chesapeake Bay: a synthesis of recent research. Maryland Sea Grant Publication, College Park, Maryland, MD, p 7-59

Boicourt WC, Kuzmic M, Hopkins TS (1999) The inland sea: circulation of Chesapeake Bay and the Northern Adriatic. In: Malone T, Malej A, Harding L, Smodlaka N, Turner R (eds) Ecosystems at the land-sea margin: drainage basin to coastal sea. American Geophysical Union, Washington, DC, $p$ 81-129

Bonsdorff E, Blomqvist EM, Mattila J, Norkko A (1997) Coastal eutrophication: causes, consequences and perspectives in the Archipelago areas of the northern Baltic Sea. Estuar Coast Shelf Sci 44(Suppl A):63-72

Borum J (1996) Shallow waters and land/sea boundaries. In: Jørgensen BB, Richardson K (eds) Eutrophication in coastal marine ecosystems. American Geophysical Union, Washington, DC, p 179-203

Borum J, Sand-Jensen K (1996) Is total primary production in shallow coastal marine waters stimulated by nitrogen loading? Oikos 76:406-410

Boynton WR, Kemp WM (1985) Nutrient regeneration and oxygen consumption by sediments along an estuarine salinity gradient. Mar Ecol Prog Ser 23:45-55

Boynton WR, Kemp WM (2000) Influence of river flow and nutrient loading on selected ecosystem processes and properties in Chesapeake Bay. In: Hobbie J (ed) Estuarine science: a synthetic approach to research and practice. Island Press, Washington, DC, p 269-298

Boynton WR, Kemp WM, Keefe CW (1982) A comparative analysis of nutrients and other factors influencing estuarine phytoplankton production. In: Kennedy VS (ed) Estuarine comparisons. Academic, New York, p 209-230

Boynton WR, Garber JH, Summers R, Kemp WM (1995) Inputs, transformations, and transport of nitrogen and phosphorus in Chesapeake Bay and selected tributaries. Estuaries 18:285-314

Bradley BP (1975) The anomalous influence of salinity and temperature on summer and winter populations of the copepod Eurytemora affinis. Biol Bull 148:26-34

Breitburg DL (1990) Nearshore hypoxia in the Chesapeake 
Bay: patterns and relationships among physical factors. Estuar Coast Shelf Sci 30:593-609

Breitburg DL (2002) Effects of hypoxia and the balance between hypoxia and enrichment, on coastal fishers and fisheries. Estuaries 25:767-781

Breitburg DL, Sanders JG, Gilmour CC, Hatfield CA, Osman RW, Riedel GF, Seitzinger SP, Sellner KG (1999) Variability in responses to nutrients and trace elements, and transmission of stressor effects through an estuarine food web. Limnol Oceanogr 44:837-863

Bricelj VM, Lonsdale DJ (1997) Aureococcus anophagefferens: causes and ecological consequences of brown tides in US mid-Atlantic coastal water. Limnol Oceanogr 42:1023-1038

Bricker SB, Stevenson JC (1996) Nutrients in coastal waters: a chronology and synopsis of research. Estuaries 19:337-341

Bricker SB, Clement CG, Pirhalla DE, Orlando SP, Farrow DRG (1999) National Estuarine Eutrophication Assessment: effects of nutrient enrichment in the nation's estuaries. NOAA, National Ocean Service, Centers for Coastal Ocean Science, Silver Spring, MD

Brush GS (1984) Stratigraphic evidence of eutrophication in an estuary. Water Resour Res 20:531-541

Brush GS (1989) Rates and patterns of estuarine sediment accumulation. Limnol Oceanogr 34:1235-1246

Brush GS, Brush LM (1994) Transport and deposition of pollen in an estuary: a signature of the landscape. In: Traverse A (ed) Sedimentation of organic particles. Cambridge University Press, Cambridge, p 33-46

Brush GS, Hilgartner WB (2000) Paleoecology of submerged macrophytes in the upper Chesapeake Bay. Ecol Monogr 70:645-667

Brush GS, Lenk C, Smith J (1980) The natural forests of Maryland: an explanation of the vegetation map of Maryland (with 1:250,000 map). Ecol Monogr 50:77-92

Bundy MH, Breitburg DL, Sellner KG (2003) The responses of Patuxent River upper trophic levels to nutrient and trace element induced changes in the lower food web. Estuaries 26:365-384

Burkholder JM, Glasgow HB (1997)The ichthyotoxic dinoflagellate Pfiesteria piscicida: behavior, impacts, and environmental controls. Limnol Oceanogr 42:1052-1075

Caddy JF (1993) Toward a comparative evaluation of human impacts on fishery ecosystems of enclosed and semienclosed seas. Rev Fish Sci 1:57-95

Caddy JF (2000) Marine catchment basin versus impacts of fisheries on semi-encloses seas. ICES J Mar Sci 57: 628-640

Cadee GC (1992) Trends in Marsdiep phytoplankton. Neth J Sea Res 20:143-149

Cadee GC, Hegeman J (1986) Seasonal and annual variations in Phaeocystis pouchetii (Haptophyceae) in the westernmost inlet of the Wadden Sea during the 1973-1985 period. Neth J Sea Res 20:29-36

Caffrey JM, Kemp WM (1990) Nitrogen cycling in sediments with estuarine populations of Potamogeton perfoliatus L and Zostera marina L. Mar Ecol Prog Ser 66:147-160

Caffrey JM, Kemp WM (1992) Influence of the submersed plant, Potamogeton perfoliatus L, on nitrogen cycling in estuarine sediments: use of ${ }^{15} \mathrm{~N}$ techniques. Limnol Oceanogr 37:1483-1495

Caraco NA, Tamse, Boutros O, Valiela I (1987) Nutrient limitation of phytoplankton phytoplankton growth in brackish coastal ponds. Can J Fish Aquat Sci 44:473-476

Carter V, Rybicki N (1986) Resurgence of submersed aquatic macrophytes in the tidal Potomac River, Maryland, Virginia, and the District of Columbia. Estuaries 9:368-375
Carter V, Rybicki NB (1990) Light attenuation and submersed macrophyte distribution in the tidal Potomac River and estuary. Estuaries 13:441-452

Carter V, Rybicki NB, Landwehr JM, Turtora M (1994) Role of weather and water quality in population dynamics of submersed macrophytes in the tidal Potomac River. Estuaries $17: 417-426$

Caumette P, Pagao M, Saint-Jean L (1983) Repartition verticale du phytoplancton, des bacteries et du zooplancton dans un milieu stratifie en Baie de Bietri (Lagune Ebrie, Cote d'Ivoire). Relations trophiques. Hydrobiologia 106: $135-148$

CBC (2003) The blue crab 2003: status of the Chesapeake population and its fisheries. Blue crab technical work group report, Chesapeake Bay Commission, Annapolis, $\mathrm{MD}$

Cederwall H, Elmgren R (1990) Biological effects of eutrophication in the Baltic Sea, particularly in the coastal zone. Ambio 19:109-112

Cloern JE (1982) Does the benthos control phytoplankton biomass in South San Francisco Bay? Mar Ecol Prog Ser 9: 191-202

Cloern JE (1987) Turbidity as a control on phytoplankton biomass and productivity in estuaries. Contin Shelf Res $7: 1367-1381$

Cloern JE (2001) Our evolving conceptual model of the coastal eutrophication problem. Mar Ecol Prog Ser 210: $223-253$

Coen LD, Luckenbach MW, Breitburg DL (1999) The role of oyster reefs as essential fish habitat: A review of current knowledge and some new perspectives. Am Fish Soc Symp 22:438-454

Cohen RRH, Dresler PV, Philips EJP, Cory RL (1984) The effect of the asiatic clam Corbicula fluminea on phytoplankton of the Potomac River, Maryland. Limnol Oceanogr 29:170-18

Colman SM, Bratton JF (2003) Athropogenic induced changes in sediment and biogenic silica fluxes in Chesapeake Bay. Geology 31:71-74

Colman SM, Baucom PC, Bratton JF, Cronin TM, McGeehin JP, Willard D, Zimerman AR, Vogt PR (2002) Radiocarbon dating, chronologic framework, and changes in accumulation rates of Holocene estuarine sediments from Chesapeake Bay. Quat Res 57:58-70

Cooper SR (1995) Chesapeake Bay watershed historical land use: impact on water quality and diatom communities. Ecol Appl 5:703-723

Cooper SR, Brush GS (1991) Long-term history of Chesapeake Bay anoxia. Science 254:992-996

Cooper SR, Brush GS (1993) A 2500-year history of anoxia and eutrophication in Chesapeake Bay. Estuaries 16: $617-626$

Cornwell JC, Sampou PA (1995) Environmental controls on iron sulfide mineral formation in a coastal plain estuary. In: Vairavamurthy MA, Schoonen MAA (eds) Geochemical transformations of sedimentary sulfur. American Chemical Society, Washington, DC, p 224-242

Cowan JLW, Boynton WR (1996) Sediment-water oxygen and nutrient exchanges along the longitudinal axis of Chesapeake Bay: seasonal patterns, controlling factors and ecological significance. Estuaries 19:562-580

Cronin TM, Vann CD(2003) The sedimentary record of climatic and anthropogenic influence on the Patuxent estuary and Chesapeake Bay ecosystems. Estuaries 26: 196-209

Cronon W (1983) Changes in the land: Indians, colonists, and the ecology of New England. Hill and Wang, New York 
Crump BC, Baross JA, Simenstad CA (1998) Dominance of particle-attached bacteria in the Columbia River estuary, USA. Aquat Microb Ecol 14:7-18

Curtin PD, Brush GS, Fisher GW (eds) (2001) Discovering the Chesapeake: the history of an ecosystem. Johns Hopkins University Press, Baltimore, MD

Dankers N, Binsbergen M, Zegers K, Laane R, van der Loeff MR (1984) Transportation of water, particulate and dissolved organic and inorganic matter between a salt marsh and the Ems-Dollard estuary, The Netherlands. Estuar Coast Shelf Sci 19:143-165

Daskalov GM (2002) Overfishing drives a trophic cascade in the Black Sea. Mar Ecol Prog Ser 225:53-63

Dauer DM, Weisburg SB, Ranasinghe JA (2000) Relationships between benthic community condition, water quality, sediment quality, nutrient loads, and land use patterns in Chesapeake Bay. Estuaries 23:80-96

D'Elia CF, Sanders JG, Boynton (1986) Nutrient enrichment studies in a coastal plain estuary: phytoplankton growth in large-scale, continuous cultures. Can J Fish Aquat Sci 43: 397-406

D'Elia CF, Boynton WR, Sanders JG (2003) A watershed perspective on nutrient enrichment, science and policy in the Patuxent River, Maryland: 1960-2000. Estuaries 26: 171-185

de Jonge VN (1990) Response of the Dutch Wadden Sea ecosystem to phosphorus discharges from the River Rhine. Hydrobiologia 195:49-62

de Jonge VN, Boynton W, D'Elia CF, Elmgren R, Welsh B (1994) Responses to developments in eutrophication in four different North Atlantic estuarine systems. In: Dyer $\mathrm{KR}$, Orth RJ (eds) Changes in fluxes in estuaries. Olsen \& Olsen, Fredensborg, p 179-196

de Jonge VN, Elliott M, Orive E (2002) Causes, historical development, effects and future challenges of a common environmental problem: eutrophication. Hydrobiologia 475/476:1-19

de Leiva Moreno JI, Agostini VN, Caddy JF, Carocci F (2000) Is the pelagic-demersal ratio from fishery landings a useful proxy for nutrient availability? A preliminary data exploration for the semi-enclosed seas around Europe. ICES J Mar Sci 57:1091-1102

Den Hartog D, Polderman PJG (1975) Changes in seagrass populations of the Dutch Waddenzee. Aquat Bot 1: 141-147

Dennison WC, Orth RJ, Moore KA, Stevenson JC, Carter V, Kollar S, Bergstrom P, Batiuk R (1993) Assessing water quality with submersed aquatic vegetation. Habitat requirements as barometers of Chesapeake Bay health. Bioscience 43:86-94

Diaz RJ (2001) Overview of hypoxia around the world. J Environ Qual 30:275-281

Diaz RJ, Rosenburg R (1995) Marine benthic hypoxia: a review of its ecological effects and the behavioral responses of benthic macrofauna. Oceanogr Mar Biol Annu Rev 33:245-303

Duarte CM (1995) Submerged aquatic vegetation in relation to different nutrient regimes. Ophelia 41:87-112

Ducklow HW, Shiah FK (1992) Bacterial production in estuaries. In: Ford $\mathrm{T}$ (ed) Aquatic microbiology: an ecological approach. Blackwell, London, p 261-287

Egge JK, Aksnes DL (1992) Silicate as regulating nutrient in phytoplankton competition. Mar Ecol Prog Ser 83:281-289

Einsele W (1936) Über die Beziehungen des Eisenkreislaufes zum Phosphatkreislauf im eutrophen See. Arch Hydrobiol 29:664-686

Eyre BD, Pont D (2003) Intra- and inter-annual variability in the different forms of diffuse nitrogen and phosphorus delivered to seven sub-tropical east Australian estuaries. Estuar Coast Self Sci 57:137-148

Fear J, Gallo T, Hall N, Loftin J, Paerl H (2004) Predicting benthic microalgal oxygen and nutrient flux responses to a nutrient reduction management strategy for the eutrophic Neuse River Estuary, North Carolina, USA. Estuar Coast Shelf Sci 61:491-506

Feigenbaum D, Kelly M (1984) Changes in the lower Chesapeake Bay food chain in presence of the sea nettle Chrysaora quinquecirrha (Scyphomedusa). Mar Ecol Prog Ser 19:39-47

Fisher TR, Peele ER, Ammerman JA, Harding LW (1992) Nutrient limitation of phytoplankton in Chesapeake Bay. Mar Ecol Prog Ser 82:51-63

Fisher TR, Gustafson AB, Sellner K, Lacouture R and 6 others (1999) Spatial and temporal variation of resource limitation in Chesapeake Bay. Mar Biol 133:763-778

Fisher TR, Gustafson AB, Radcliffe GR, Sundberg KL, Stevenson JC (2003) A long-term record of photosynthetically active radiation (PAR) and total solar energy at $38.6^{\circ} \mathrm{N}$, $78.2^{\circ} \mathrm{W}$. Estuaries 26:1450-1460

Froomer NL (1980) Sea level changes in the Chesapeake Bay during historic times. Mar Geol 36:289-305

Gallegos CL (2001) Calculating optical water quality targets to restore and protect submersed aquatic vegetation: overcoming problems in partitioning the diffuse attenuation coefficient for photosynthetically active radiation. Estuaries 24:381-397

Gallegos CL, Jordan TE (2002) Impact of the spring 2000 phytoplankton bloom in Chesapeake Bay on optical properties and light penetration in the Rhode River, Maryland. Estuaries 25:508-518

Gavis J, Grant V (1986) Sulfide, iron, manganese, and phosphate in the deep-water of the Chesapeake Bay during anoxia. Estuar Coast Shelf Sci 23:451-463

Gerritsen J, Holland AF, Irvine DE (1994) Suspension-feeding bivalves and the fate of primary production: an estuarine model applied to Chesapeake Bay. Estuaries 17:403-416

Giesen WBJT, van Katwijk MM, den Hartog C (1990) Eelgrass conditions and turbidity in the Dutch Wadden Sea. Aquat Bot 37:71-85

Glibert PM, Magnien R, Lomas MW, Alexander J, Fan C, Haramoto E, Trice M, Kana TM (2001) Harmful algal blooms in the Chesapeake and Coastal Bays of Maryland, USA: comparisons of 1997, 1998, and 1999 events. Estuaries 24:875-883

Glibert PM, Magnien RE (2004) Harmful algal blooms in Chesapeake Bay, USA: common species, relationships to nutrient loading, management approaches, successes and challenges. In: Hall S, Anderson D, Kleindinst J, Zhu M (eds) Harmful algae management and mitigation. AsiaPacific Economic Cooperation Publications (204-MR-04.2), Singapore, p 48-55

Goodrich DM, Boicourt WC, Hamilton P, Pritchard DW (1987) Wind-induced destratification in Chesapeake Bay. J Phys Oceanogr 17:2232-2240

Graco M, Farias L, Molina V, Gutierrez D, Nielsen LP (2001) Massive developments of microbial mats following phytoplankton blooms in a naturally eutrophic bay: implications for nitrogen cycling. Limnol Oceanogr 46:821-832

Graneli E, Wallström K, Larsson U, Graneli W, Elmgren R (1990) Nutrient limitation of primary production in the Baltic Sea area. Ambio 19:142-151

Gray JS (1992) Eutrophication in the sea. In: Colombo G, Ferrari I, Cecchereli VU, Rossi R (eds) Marine eutrophication and population dynamics. Olsen \& Olsen, Fredensborg, p 3-15 
Gucu AC (2002) Can overfishing be responsible for the successful establishment of Mnemiopsis leidyi in the Black Sea? Estuar Coast Shelf Sci 54:439-451

Hagy JD (2002) Eutrophication, hypoxia and trophic transfer efficiency in Chesapeake Bay. PhD dissertation, University of Maryland, College Park, MD

Hagy JD, Boynton WR, Wood CW, Wood KV (2004) Hypoxia in Chesapeake Bay, 1950-2001: long-term changes in relation to nutrient loading and river flow. Estuaries 27:634-658

Harding Jr. LW (1994) Long-term trends in the distribution of phytoplankton in Chesapeake Bay: roles of light, nutrients and streamflow. Mar Ecol Prog Ser 104:267-291

Harding Jr LW, Perry ES (1997) Long-term increase of phytoplankton biomass in Chesapeake Bay, 1950-1994. Mar Ecol Prog Ser 157:39-52

Harding Jr LW, Mallonee ME, Perry ES (2002) Toward a predictive understanding of primary productivity in a temperate, partially stratified estuary. Estuar Coast Shelf Sci 55: $437-463$

Harwell MC, Orth RJ (2002) Seed bank patterns in Chesapeake Bay eelgrass (Zostera marina L.): a bay-wide perspective. Estuaries 25:1196-1204

Hearn CJ, Robson BJ (2001) Inter-annual variability of bottom hypoxia in shallow mediterranean estuaries. Estuar Coast Shelf Sci 52:643-657

Heil CA (2005) Influence of humic, fulvic and hydrophilic acids on the growth, photosynthesis and respiration of the dinoflagellate Prorocentrum minimum (Pavillard) Schiller. Harmful Algae 4:603-618

Heinle DR (1966) Production of a calanoid copepod, Acartia tonsa, in the Patuxent River estuary. Chesapeake Sci 7 : $59-74$

Heinle DR, Flemer DA (1976) Flows of materials between poorly flooded marshes and an estuary. Mar Biol 35: 359-373

Heinle DR, D'Elia CF, Taft JL, Wilson JS, Cole-Jones M, Caplins AB, Cronin LE (1980) Historical review of water quality and climatic data from Chesapeake Bay with emphasis on effects of enrichment. USEPA Chesapeake Bay Program Report, Publication 84, Chesapeake Research Consortium, Edgewater, MD

Heinle DR, Harris RP, Ustach JF, Flemer DA (1977) Detritus as food for estuarine copepods. Mar Biol 40:341-353

Hemminga MA, Harrison PG, van Lent F (1991) The balance of nutrient losses and gains in seagrass meadows. Mar Ecol Prog Ser 71:85-96

Henriksen K, Kemp WM (1988) Nitrification in estuarine and coastal marine sediments: methods, patterns and regulating factors. In: Blackburn TH, Sørensen J (eds) Nitrogen cycling in coastal marine environments. Wiley, New York, p 207-249

Herman PMJ, Middleburg JJ, Van De Koppel J, Heip CHR (1999) Ecology and estuarine macrobenthos. Adv Ecol Res 29:195-240

Holland AF, Mountford NK, Mihursky JA (1977) Temporal variation in upper Bay mesohaline benthic communities. I. The 9-m mud habitat. Chesapeake Sci 18:370-378

Holland AF, Shaughnessy AT, Hiegel MH (1987) Long-term variation in mesohaline Chesapeake Bay macrobenthos: spatial and temporal patterns. Estuaries 10:227-245

Houde ED, Jukic-Peladic S, Brandt SB, Leach SD (1999) Fisheries: trends in catches, abundances and management. In: Malone TC, Malej A, Harding Jr LW, Smodlaka N, Turner E (eds) Ecosystems at the land-sea margin: drainage basin to coastal sea. American Geophysical Union, Coastal and Estuarine Studies, Vol 55, p 341-346

Howarth R, Anderson D, Cloern J, Elfring C and 7 others
(2000) Nutrient pollution of coastal rivers, bays, and seas. Issues Ecol 7:1-15

Hutchinson GE (1969) Eutrophication, past and present. In: Rohlich RA (ed) Eutrophication: causes, consequences and correctives. National Academy of Sciences, Washington, DC, p 17-26

Jackson JBC and 18 others (2001) Historical overfishing and the recent collapse of coastal ecosystems. Science 293: 629-637

Jansson BO (1978) The Baltic-a systems analysis of a semienclosed sea. In: Charnock H, Deacon G (eds) Advances in oceanography. Plenum, New York, p 131-183

Jaworski N (1990) Retrospective of the water quality issues of the upper Potomac estuary. Aquat Sci 3:11-40

Jeppesen E, Søndergaard M, Jensen JP, Mortensen E, Hansen AH, Jørgensen T (1998) Cascading trophic interactions from fish to bacteria and nutrients after reduced sewage loading: an 18-year study of a shallow hypertrophic lake. Ecosystems 1:250-267

Johannessen T, Dahl E (1996) Declines in oxygen concentration along the Norwegian Skagerrak coast, 1927-1993: a signal of ecosystem changes due to eutrophication? Limnol Oceanogr 41:766-778

Jonas RB (1997) Bacteria, dissolved organics and oxygen consumption in salinity stratified Chesapeake Bay, an anoxia paradigm. Am Zool 37:612-620

Jones RC (2000) Long-term trends in phytoplankton chlorophyll a in the tidal freshwater Potomac River, USA: relationship to climate and management factors. Verh Int Ver Theor Angew Limnol 27:2959-2962

Joye SB, Hollibaugh JT (1995) Influence of sulfide inhibition of nitrification on nitrogen regeneration in sediments. Science 270:623-625

Jupp BP, Spence DHN (1977) Limitations on macrophytes in a eutrophic lake, Loch Leven. I. Effects of phytoplankton. J Ecol 65:175-186

Justić D, Rabalais NN, Turner RE (1996) Effects of climate change on hypoxia in coastal waters: a doubled $\mathrm{CO}_{2}$ scenario for the northern Gulf of Mexico. Limnol Oceanogr 41:992-1003

Karlsen AW, Cronin TM, Ishman ES, Willard DA, Holmes CW, Marot M, Kerhin R (2000) Historical trends in Chesapeake Bay dissolved oxygen based on benthic Foraminifera from sediment cores. Estuaries 23:488-508

Kauppila P, Meeuwig JJ, Pitkanen H (2003) Predicting oxygen in small estuaries of the Baltic Sea: a comparative approach. Estuar Coast Shelf Sci 57:1115-1126

Kearney MS (1996) Sea-level change during the last thousand years in Chesapeake Bay. J Coast Res 12:977-983

Kearney MS, Grace RE, Stevenson JC (1988) Marsh loss in the Nanticoke Estuary, Chesapeake Bay. Geogr Rev 78: 205-220

Kearney MS, Rogers AS, Townsend JPRG, Rizzo E, Stutzer D, Stevenson JC, Sundberg KL (2002) Landsat imagery shows decline of coastal marshes in Chesapeake and Delaware Bays. EOS 3:173-178

Keister JE, Houde ED, Brietburg DL (2000) Effects of bottomlayer hypoxia on abundances and depth distributions of organisms in Patuxent River, Chesapeake Bay. Mar Ecol Prog Ser 205:43-59

Kemp WM, Boynton WR (1981) External and internal factors regulating metabolic rates of an estuarine benthic community. Oecologia 51:19-27

Kemp WM, Boynton WR, Stevenson JC, Twilley RR, Means JC (1983) The decline of submerged vascular plants in upper Chesapeake Bay: summary of results concerning possible causes. Mar Technol Soc J 17:78-89 
Kemp WM, Boynton WR, Twilley RR, Stevenson JC, Ward LG (1984) Influences of submersed vascular plants on ecological processes in upper Chesapeake Bay. In: Kennedy VS (ed) Estuaries as filters. Academic, New York, p 367-394

Kemp WM, Sampou P, Caffrey J, Mayer M, Henriksen K, Boynton WR (1990) Ammonium recycling versus denitrification in Chesapeake Bay sediments. Limnol Oceanogr 35:1545-1563

Kemp WM, Sampou PA, Garber J, Tuttle J, Boynton WR (1992) Seasonal depletion of oxygen from bottom waters of Chesapeake Bay: relative roles of benthic and planktonic respiration and physical exchange processes. Mar Ecol Prog Ser 85:137-152

Kemp WM, Smith EM, Marvin-DiPasquale M, Boynton WR (1997) Organic carbon-balance and net ecosystem metabolism in Chesapeake Bay. Mar Ecol Prog Ser 150:229-248

Kemp WM, Puskaric S, Faganeli A, Smith E, Boynton W (1999) Pelagic-benthic coupling and nutrient cycling. In: Malone T, Malej A, Harding L, Smodlaka N, Turner R (eds) Ecosystems at the land-sea margin: drainage basin to coastal sea. American Geophysical Union, Washington, DC, p 295-339

Kemp WM, Brooks MT, Hood RR (2001) Nutrient enrichment, habitat variability and trophic transfer efficiency in simple models of pelagic ecosystems. Mar Ecol Prog Ser 223: 73-87

Kemp WM, Batiuk R, Bartleson R, Bergstrom P and 12 others (2004) Habitat requirements for submerged aquatic vegetation in Chesapeake Bay: water quality, light regime, and physical-chemical factors. Estuaries 27:263-377

Kennedy VS, Breisch LL (1981) Maryland's oysters, research and management, Maryland Sea Grant, University of Maryland, College Park, MD

Kimmel DG, Roman MR (2004) Long-term trends in mesozooplankton abundance in Chesapeake Bay USA: influence of freshwater input. Mar Ecol Prog Ser 267:71-83

Kirby MX, Miller HM (2005) Response of a benthic suspension feeder (Crassostrea virginica Gmelin) to three centuries of anthropogenic eutrophication in Chesapeake Bay. Estuar Coast Shelf Sci 62:679-689

Klingel GC (1951) The Bay. Johns Hopkins University Press, Baltimore, MD

Lawrence D, Valiela I, Tomasky G (2004) Estuarine calanoid copepod abundance in relation to season, salinity, and land-derived nitrogen loading, Waquoit Bay, Massachusetts. Estuar Coast Shelf Sci 61:547-557

Lehmusluoto PO (1973) Eutrophication in the Helsinki and Espoo sea areas measured as phytoplankton primary production. Oikos (Suppl) 15:202-208

Likens GE (1972) Eutrophication and aquatic ecosystems. In: Likens GE (ed) Nutrients and eutrophication: the limiting nutrient controversy. Allen Press, Lawrence, KS, p 3-13

Llanso RJ (1992) Effects of hypoxia on estuarine benthos: the lower Rappahannock River (Chesapeake Bay), a case study. Estuar Coast Shelf Sci 35:491-515

Lomas MW, Glibert PM, Clougherty DA, Huber DE, Jones J, Alexander J, Haramoto E (2001) Elevated organic nutrient ratios associated with brown tide blooms of Aureococcus anophagefferens (Pelagophyceae). J Plankton Res 23: 1339-1344

Loo LO, Rosenberg R (1989) Bivalve suspension-feedeing dynamics and benthic-pelagic coupling in an eutrophicated marine bay. J Exp Mar Biol Ecol 130:253-276

Lubbers L, Boynton WR, Kemp WM (1990) Variations in structure of estuarine fish communities in relation to abundance of submersed vascular plants. Mar Ecol Prog Ser 65: $1-14$
Luckenbach MW, Sellner KG, Shumway SE, Greene K (1993) Effects of two bloom-forming dinoflagellates, Prorocentrum minimum and Gyrodinium uncatenum, on the growth and survival of the Eastern Oyster, Crassostrea virginica (Gmelin 1791). J Shellfish Res 12:411-415

Lukatelich RJ, McComb AJ (1986) Nutrient levels and the development of diatom and blue-green algal blooms in a shallow Australian estuary. J Plankton Res 8:597-618

Luo J, Hartman KJ, Brandt SB, Cerco CF (2001) A spatiallyexplicit approach for estimating carrying capacity: an application for the Atlantic menhaden (Brevortia tyrannus) in Chesapeake Bay. Estuaries 24:545-556

Madsen KN, Nilsson P, Sundback K (1993) The influence of benthic microalgae on the stability of a subtidal sediment. J Exp Mar Biol Ecol 170:159-177

Malone T, Kemp WM, Ducklow H, Boynton W, Tuttle J, Jonas $\mathrm{R}$ (1986) Lateral variation in the production and fate of phytoplankton in a partially stratified estuary. Mar Ecol Prog Ser 32:149-160

Malone TC, Boynton W, Horton T, Stevenson C (1993) Nutrient loading to surface waters: Chesapeake case study. In: Uman MF (ed) Keeping pace with science and engineering. National Academy Press, Washington, DC, p 8-38

Marba N, Duarte CM (1997) Interannual changes in seagrass (Posidonia oceanica) growth and environmental change in the Spanish Mediterranean littoral zone. Limnol Oceanogr 42:800-810

Marshall HG (1994) Chesapeake Bay phytoplankton. I. Composition. Proc Biol Soc Wash 107:573-585

Marshall HG, Lacouture R (1986) Seasonal patterns of growth and composition of phytoplankton in the lower Chesapeake Bay and vicinity. Estuar Coast Shelf Sci 23:115-130

Marvin-DiPasquale MC, Capone DG (1998) Benthic sulfate reduction along the Chesapeake Bay central channel. I. Spatial trends and controls. Mar Ecol Prog Ser 168:213-228

Mayer MS, Schaffner L, Kemp WM (1995) Nitrification potentials of benthic macrofaunal tubes and burrow walls: effects of sediment $\mathrm{NH}_{4}{ }^{+}$and animal irrigation behavior. Mar Ecol Prog Ser 121:157-169

Melvasalo T, Pesonen L, Varmo R, Viljamaa H (1975) Inshore effects of pollution on the biota of the Baltic, Southern Finland. Verh Internat Verein Limnol 19:2340-2353

Menesguen A, Piriou PY (1995) Nitrogen loadings and macroalgal (Ulva sp.) mass accumulation in Brittany (France). Ophelia 42:227-237

Merrill JZ, Cornwell JC (2000) The role of oligohaline marshes in estuarine nutrient cycling. In: Weinstein MP, Kreeger DA (eds) Concepts and controversies in tidal marsh ecology. Kluwer, Dordrecht, p 425-441

Meybeck M (1998) Man and river interface: multiple impacts on water and particulates chemistry illustrated in the Seine river basin. Hydrobiol 373/374:1-20

Miller DC, Geider RJ, MacIntyre HL (1996) Microphytobenthos: The ecological role of the 'secret garden' of unvegetated, shallow-water marine habitats. II. Role in sediment stability and shallow-water food webs. Estuaries 19:202-212

Monbet Y (1992) Control of phytoplankton biomass in estuaries: a comparative analysis of microtidal and macrotidal estuaries. Estuaries 15:563-571

Moore KA, Wetzel RL (2000) Seasonal variations in eelgrass (Zostera marina L.) responses to nutrient enrichment and reduced light availability in experimental ecosystems. J Exp Mar Biol Ecol 244:1-28

Mortimer CH (1941) The exchange of dissolved substances between mud and lake water. J Ecol 29:280-329

Murray L, Wetzel RL (1987) Oxygen production and con- 
sumption associated with the major autotrophic components in two temperate seagrass communities. Mar Ecol Prog Ser 38:231-239

Nagai T (2003) Recovery of fish stocks in the Seto Inland Sea. Mar Pollut Bull 47:126-131

Neckles HA, Wetzel RL, Orth RJ (1993) Relative effects of nutrient enrichment and grazing on epiphyte-macrophyte (Zostera marina L.) dynamics. Oecologia 93:285-295

Neundorfer JV, Kemp WM (1993) Nitrogen versus phosphorus enrichment of brackish waters: Response of Potomogeton perfoliatus and its associated algal communities. Mar Ecol Prog Ser 94:71-82

Newcombe CL, Horne WA (1938) Oxygen-poor waters in the Chesapeake Bay. Science 88:80-81

Newcombe CL, Horne WA, Shepherd BB (1939) Studies on the physics and chemistry of estuarine waters in Chesapeake Bay. J Mar Res 2:87-116

Newell RIE (1988) Ecological Changes in Chesapeake Bay: Are they the result of overharvesting the Eastern oyster (Crassostrea virginica)? In: Lynch MP, Krome EC (eds) Understanding the estuary: advances in Chesapeake Bay research. Chesapeake Research Consortium Publication 129 (CBP/TRS 24/88). Gloucester Point, VA, p 536-546

Newell RIE, Koch EW (2004) Modeling seagrass density and distribution in response to changes in turbidity from bivalve filtration and seagrass sediment stabilization. Estuaries 27:793-806

Newell RIE, Cornwell J, Owens MS (2002) Influence of simulated bivalve biodeposition and microphytobenthos on sediment nitrogen dynamics: a laboratory study. Limnol Oceanogr 47:1367-1379

Newell RIE, Fisher TR, Holyoke RR, Cornwell JC (2005) Influence of eastern oysters on $\mathrm{N}$ and $\mathrm{P}$ regeneration in Chesapeake Bay, USA. In: Dame R, Olenin S (eds) The comparative roles of suspension feeders in ecosystems. Springer, Berlin, p 93-12

Nielsen SL, Sand-Jensen K, Borum J, Geertz-Hansen O (2002a) Phytoplankton, nutrients and transparency in Danish coastal waters. Estuaries 25:930-937

Nielsen SL, Sand-Jensen K, Borum J, Geertz-Hansen O (2002b) Depth colonization of eelgrass (Zostera marina) and macroalgae as determined by water transparency in Danish coastal waters. Estuaries 25:1025-1032

Niklitschek EJ (2001) Bioenergetics modeling and assessment of suitable habitat for juvenile Atlantic and shortnose sturgeons (Acipenser oxyrinchus and $A$. brevirostrum) in the Chesapeake Bay. PhD dissertation, University of Maryland, College Park, MD

Nixon SW (1980) Between coastal marshes and coastal waters-a review of twenty years of speculation and research on the role of salt marshes in estuarine productivity and water chemistry. In: Hamilton P, MacDonald KB (eds) Estuarine and wetland processes with emphasis on modeling. Plenum, New York, p 437-526

Nixon SW (1995) Coastal marine eutrophication: a definition, social causes, and future concerns. Ophelia 41:199-219

Nixon SW, Buckley BA (2002) 'A strikingly rich zone'—nutrient enrichment and secondary production in coastal marine ecosystems. Estuaries 25:782-796

Nixon SW, Ammerman JW, Atkinson LP, Berounsky VM and 12 others (1996) The fate of nitrogen and phosphorus at the land-sea margin of the North Atlantic Ocean. Biogeochemistry 35:141-180

North EW, Houde ED (2003) Linking ETM physics, zooplankton prey, and fish early-life histories to striped bass Morone saxatilis and white perch $M$. americana recruitment. Mar Ecol Prog Ser 260:219-236
NRC (2004) Nonnative oysters in the Chesapeake Bay. Committee on Nonnative Oysters in the Chesapeake Bay, National Research Council, National Academy of Sciences USA, Washington, DC

Officer CB, Biggs RB, Taft JL, Cronin LE, Tyler MA, Boynton WR (1984) Chesapeake Bay anoxia: origin, development and significance. Science 223:22-27

Orth RJ, Moore KA (1983) Chesapeake Bay: an unprecedented decline in submerged aquatic vegetation. Science 222:51-53

Orth RJ, van Montfrans J (1990) Utilization of marsh and seagrass habitats by early stages of Callinectes sapidus: a latitudinal perspective. Bull Mar Sci 46:126-144

Paasche E, Erga SR (1988) Phosphorus and nitrogen limitation of phytoplankton in the inner Oslofjord (Norway). Sarsia 73:229-243

Paerl HW (1988) Nuisance phytoplankton blooms in coastal, estuarine, and inland waters. Limnol Oceanogr 33:823-847

Paerl HW, Bales LM, Joyner AR, Piehler MF (2004) Solving problems resulting from solutions: Evolution of a dual nutrient management strategy for the eutrophying Neuse River estuary, North Carolina. Environ Sci Technol 38: 3068-3073

Park GS, Marshall HG (2000) Estuarine relationships between zooplankton community structure and trophic gradients. J Plankton Res 22:121-135

Pelegri SP, Nielsen LP, Blackburn TH (1994) Denitrification in estuarine sediment simulated by the irrigation activity of the amphipod Corophium voluator. Mar Ecol Prog Ser 105:285-290

Phelps HL (1994) The Asiatic clam (Corbicula fluminea) invasion and system-level ecological changes in the Potomac River estuary near Washington, DC. Estuaries 17:614-621

Phillips GL, Eminson D, Moss B (1978) A mechanism to account for macrophyte decline in progressively eutrophicated freshwaters. Aquat Bot 4:103-126

Pihl L, Baden SP, Diaz RJ, Schaffner LC (1992) Hypoxiainduced structural changes in the diet of bottom-feeding fish and Crustacea. Mar Biol 112:349-361

Pritchard DW (1956) The dynamic structure of a coastal plain estuary. J Mar Res 15:33-42

Pritchard DW (1967) Observations of circulation in coastal plain estuaries. In: Lauff GH (ed) Estuaries. American Association for the Advancement of Science, Washington, DC, p 37-44

Purcell JE, Cowan JH (1995) Predation by the scyphomedusan Chrysaora quinquecirrha on Mnemiopsis leidyi ctenophores. Mar Ecol Prog Ser 129:63-70

Purcell JE, Decker MB (2005) Effects of climate on relative predation by scyphomedusae and ctenophores on copepods in Chesapeake Bay during 1987-2000. Limnol Oceanogr 50:376-387

Purcell JE, White JR, Nemazie DA, Wright DA (1999) Temperature, salinity and food effects on asexual reproduction and abundance of the scyphozoan Chrysaora quinquecirrha. Mar Ecol Prog Ser 180:187-196

Radach G (1992) Ecosystem functioning in the German Bight under continental nutrient inputs by rivers. Estuaries 15: 477-496

Rafaelli DG, Raven JA, Poole LJ (1998) Ecological impact of green macroalgal blooms. Oceanogr Mar Biol Annu Rev 36:97-125

Reay WG, Gallagher DL, Simmons GM (1995) Sedimentwater column oxygen and nutrient fluxes in near shore environments of the lower Delmarva peninsula, USA. Mar Ecol Prog Ser 118:215-227

Richards RA, Rago PJ (1999) A case history of effective fishery 
management: Chesapeake Bay striped bass. N Am J Fish Manage 19:356-375

Richardson K, Jørgensen BB (1996) Eutrophication: definition, history and effects. In: Richardson $\mathrm{K}$, Jørgensen BB (eds) Eutrophication in coastal marine ecosystems. American Geophysical Union, Washington, DC, p 1-19

Rilling GC, Houde ED (1999) Regional and temporal variability in distribution and abundance of bay anchovy (Anchoa mitchilli) eggs, larvae, and adult biomass in the Chesapeake Bay. Estuaries 22:1096-1109

Risgaard-Petersen N, Dalsgaard T, Rysgaard S, Kristensen PBC, Borum J, McGlathery K, Nielsen LP (1998) Nitrogen balance of a temperate eelgrass Zostera marina bed. Mar Ecol Prog Ser 174:281-291

Rizzo WM, Wetzel RL (1985) Intertidal and shoal benthic community metabolism in a temperate estuary: studies of spatial and temporal scales of variability. Estuaries 8:342-351

Rizzo WM, Lackey GJ, Christian RR (1992) Significance of euphotic, subtidal sediments to oxygen and nutrient cycling in a temperate estuary. Mar Ecol Prog Ser 86:51-61

Roberts WP, Pierce JW (1974) Sediment yield in the Patuxent River (MD) undergoing urbanization, 1968-1969. Sed Geol 12:179-197

Roden EE, Tuttle JH (1992) Sulfide release from estuarine sediments underlying anoxic bottom water. Limnol Oceanogr 37:725-738

Roden EE, Tuttle JH (1993) Inorganic sulfur cycling in mid and lower Chesapeake Bay sediments. Mar Ecol Prog Ser 93:101-118

Roman MR, Gauzens AL, Rhinehart WK, White JR (1993) Effects of low oxygen waters on Chesapeake Bay zooplankton. Limnol Oceanogr 38:1603-1614

Roman MR, Holliday DV, Sanford LP (2001) Temporal and spatial patterns of zooplankton in the Chesapeake Bay turbidity maximum. Mar Ecol Prog Ser 213:215-227

Rosenberg R (1985) Eutrophication-the future marine coastal nuisance? Mar Poll Bull 16:227-231

Rosenberg R (1990) Negative oxygen trends in Swedish coastal bottom waters. Mar Pollut Bull 21:335-339

Rothschild BJ, Ault JS, Goulletquer P, Heral M (1994) Decline of the Chesapeake Bay oyster population: a century of habitat destruction and overfishing. Mar Ecol Prog Ser 111:29-39

Ruffin KK (1998) The persistence of anthropogenic turbidity plumes in a shallow water estuary. Estuar Coast Shelf Sci 47:579-592

Rybicki NB, Jenter HL, Carter V, Baltzer RA, Turtora M (1997) Observations of the tidal flux between a submersed aquatic plant stand and the adjacent channel in the Potomac River near Washington, DC. Limnol Oceanogr 42:307-317

Rybicki NB, McFarland DG, Ruhl HA, Reel JT, Barko JW (2001) Investigations of the availability and survival of submersed aquatic vegetation propagules in the tidal Potomac River. Estuaries 24:407-424

Ryther JH, Dunstan WM (1971) Nitrogen, phosphorus and eutrophication in the coastal marine environment. Science 171:1008-1013

Sand-Jensen K, Borum J (1991) Interactions among phytoplankton, periphyton, and marcrophytes in temperate freshwater and estuaries. Aquat Bot 41:137-175

Sanford LP, Sellner KG, Breitburg DL (1990) Covariability of dissolved oxygen with physical processes in the summertime Chesapeake Bay. J Mar Res 48:567-590

Schaffner LC, Jonsson P, Diaz RJ, Rosenberg R, Gapcynski P (1992) Benthic communities and bioturbation history of estuarine and coastal systems: effects of hypoxia and anoxia. Sci Total Environ (Suppl):1001-1016
Scheffer M, Carpenter SR (2003) Catastrophic regime shifts in ecosystems: linking theory to observations. Trends Ecol Evol 18:648-656

Schindler DW (1981) Studies of eutrophication in lakes and their relevance to the estuarine environment. In: Neilson BJ, Cronin LE (eds) Estuaries and nutrients. Humana Press, Totowa, NJ, p 71-82

Schubel JR, Hirschberg DJ (1978) Estuarine graveyards, climatic change, and the importance of the estuarine environment. In: Wiley ML (ed) Estuarine interactions. Academic, New York, p 285-303

Schubel JR, Pritchard DW (1986) Responses of upper Chesapeake Bay to variations in discharge of the Susquehanna River. Estuaries 9:236-249

Seitzinger SP (1991) The effect of $\mathrm{pH}$ on the release of phosphorus from Potomac estuary sediments: implications for blue-green algal blooms. Estuar Coast Shelf Sci 33: 409-418

Seliger HH, Boggs JA (1988) Long term pattern of anoxia in the Chesapeake Bay. In: Lynch M, Krome EC (eds) Understanding the estuary: advances in Chesapeake Bay research. Publication Number 129, Chesapeake Research Consortium, Edgewater, MD, p 570-583

Sellner KG, Lacouture RV, Parrish CR (1988) Effects of increasing salinity on a cyanobacteria bloom in the Potomac River estuary. J Plankton Res 10:49-61

Short FT, Wyllie-Echeverria S (1996) Natural and humaninduced disturbance of seagrasses. Environ Conserv 23: $17-27$

Short FT, Burdick DM, Kaldy JE (1995) Mesocosm experiments quantify the effects of eutrophication on eelgrass, Zostera marina. Limnol Oceanogr 40:740-749

Smayda TJ (1990) Novel and nuisance phytoplankton blooms in the sea: evidence for a global epidemic. In: Graneli E, Sundstrom B, Edler L, Anderson DM (eds) Toxic marine phytoplankton. Elsevier, New York, p 29-40

Smayda TJ (1997) Harmful algal blooms: their ecophysiology and general relevance to phytoplankton blooms in the sea. Limnol Oceanogr 42:1137-1153

Smetacek V, Bathmann U, Nothig EM, Scharek R (1991) Coastal eutrophication: causes and consequences. In: Mantoura RFC, Martin JM, Wollast R (eds) Ocean margin processes in global change. Wiley, New York, p 251-279

Smith SV (1984) Phosphorus versus nitrogen limitation in the marine environment. Limnol Oceanogr 29:1149-1160

Smith VH (2003) Eutrophication of freshwater and coastal marine ecosystems: A global problem. Environ Sci Pollut Res 10:1-14

Smith SV, Swaney, DP, Talaue-McManus L, Bartley JD and 7 others (2003a) Humans, hydrology, and the distribution of inorganic nutrient loading to the ocean. BioScience 53: $235-245$

Smith GF, Roach EB, Bruce DG (2003b) The location, composition, and origin of oyster bars in mesohaline Chesapeake Bay. Estuar Coast Shelf Sci 56:391-409

Sönderström J (1971) The capacity of coastal waters to use nutrients in Bohuslän, Sweden. Bot Mar 14:39-52

Souchu P, Vaquer A, Collos, Y, Landrein S, Deslous-Paoli JM, Bibern B (2001) Influence of shellfish farming activities on the biogeochemical composition of the water column in Thau lagoon. Mar Ecol Prog Ser 218:141-152

Sprague LA, Langland MJ, Yochum SE, Edwards RE, Blomquist JD, Phillips SW, Shenk GW, Preston SD (2000) Factors affecting nutrient trends in major rivers of the Chesapeake Bay watershed. Water Resources Investigations Report 00-4218. US Geological Survey, Richmond, VA

Stankelis RM, Naylor MD, Boynton WR (2003) Submerged 
aquatic vegetation in the mesohaline region of the Patuxent Estuary: past, present, and future status. Estuaries 26: 186-195

Stevenson JC, Kearney MS (1996) Shoreline dynamics on the windward and leeward shores of a large temperate estuary. In: Nordstrom KF, Roman CT (eds) Estuarine shores: hydrological, geomorphological and ecological interactions. Wiley, New York, p 233-259

Stevenson JC, Heinle DR, Flemer DA, Small RJ, Rowland RA, Ustach JF (1977) Nutrient exchanges between brackish water marshes and the estuary. In: Wiley M (ed) Estuarine processes. Academic, New York, p 219-240

Stevenson JC, Kearney MS, Pendelton EC (1985) Sedimentation and erosion in a Chesapeake Bay brackish marsh system. Mar Geol 67:213-235

Stevenson JC, Staver LW, Staver KW (1993) Water quality associated with survival of submersed aquatic vegetation along an estuarine gradient. Estuaries 16:346-361

Stevenson JC, Maarusic JI, Ozretic B, Marson A, Cecconni G, Kearney MS (1999) Shallow water and shoreline ecosystems of Chesapeake Bay compared with the Adriatic Sea: transformation of habitat at the land sea margin. In: Malone TC, Malej A, Smodlaka N, Turner RE (eds) Ecosystems at the land sea margin-drainage basin to coastal sea. American Geophysical Union, Washington, DC, p 29-80

Stevenson JC, Rooth JE, Kearney MS, Sundberg KL (2000) The health and long term stability of natural and restored marshes in Chesapeake Bay. In: Weinstein MP, Kreeger DA (eds) Concepts and controversies in tidal marsh ecology. Kluwer, Dordrecht, p 709-735

Stevenson JC, Kearney MS, Koch EW (2002) Impacts of sealevel rise on tidal wetlands and shallow water habitats: a case study from Chesapeake Bay. In: McGinn NA (ed) Fisheries in a Changing Environment. American Fisheries Society Symposium No. 32, p 23-36

Strayer DL, Caraco NF, Cole JJ, Findlay S, Pace ML (1999) Transformation of freshwater ecosystems by bivalves. BioScience 49:19-27

Sturgis RB, Murray L (1997) Scaling of nutrient inputs to submersed plant communities: temporal and spatial variations. Mar Ecol Prog Ser 152:89-102

Stumm W, Morgan JJ (1970) Aquatic chemistry. WileyInterscience, New York

Sundbäck K, Miles A, Göransson E (2000) Nitrogen fluxes, denitrification and the role of microphytobenthos in microtidal shallow-water sediments: an annual study. Mar Ecol Prog Ser 200:59-76

Taft JL, Taylor WR, Hartwig EO, Loftus R (1980) Seasonal oxygen depletion in Chesapeake Bay. Estuaries 3:242-247

Thompson ML, Schaffner LC (2001) Population biology and secondary production of the suspension feeding polychaete Chaetopterus cf. variopedatus: implications for benthic-pelagic coupling in lower Chesapeake Bay. Limnol Oceanogr 46:1899-1907

Trice TM, Glibert PM, Lea C, Van Heukelem L (2004) HPLC pigment records provide evidence of past blooms of Aureococcus anophagefferens in the Coastal Bays of Maryland and Virginia, USA. Harmful Algae 3:295-304

Turner RE (2001) Some effects of eutrophication on pelagic and demersal marine food webs. In: Rabblais NN, Turner RE (eds) Coastal hypoxia: Consequences for living resources and ecosystems. Am Geophys Union, Washington DC, p 371-398

Editorial responsibility: Otto Kinne (Editor-in-Chief), Oldendorf/Luhe, Germany
Twilley RR, Kemp WM, Staver KW, Stevenson J, Boynton WR (1985) Nutrient enrichment of estuarine submersed vascular plant communities. I. Algal growth and effects on production of plants and associated communities. Mar Ecol Prog Ser 23:179-191

Tyler AC, McGlathery KJ, Anderson IC (2003) Benthic algae control sediment-water column fluxes of organic and inorganic nitrogen compounds in a temperate lagoon. Limnol Oceaongr 48:2125-2137

Ulanowicz RE, Tuttle JH (1992) The trophic consequences of oyster stock rehabilitation in Chesapeake Bay. Estuaries 15:298-306

Vadeboncoeur YE, Jeppesen MJ, Van der Zanden $\mathrm{HH}$, Schierup K, Christoffersen, Lodge DM (2003) From Greenland to green lakes: cultural eutrophication and the lass of benthic pathways in lakes. Limnol Oceanogr 48: 1408-1418

Valiela I, Boynton W, Hollibaugh JT, Jay D, Kemp WM, Kremer J, Simenstad C, Smith SV (1992) Understanding changes in coastal environments: the LMER Program. EOS 73:481-485

Valiela I, McClelland J, Hauxwell J, Behr PJ, Hersh D, Foreman K (1997) Macroalgal blooms in shallow estuaries: controls and ecophysiological and ecosystem consequences. Limnol Oceanogr 42:1105-1118

Valiela I, Cole ML, McClelland J, Hauxwell J, Cebrian J, Joye SB (2000) Role of salt marshes as part of coastal landscapes. In: Weinstein MP, Kreeger DA (eds) Concepts and controversies in tidal marsh ecology. Kluwer, Dordrecht, p 23-28

Verhoeven JTA (1979) The ecology of Ruppia-dominated communities in Western Europe. I. Distribution of Ruppia representatives in relation to their autecology. Aquat Bot 6:197-268

Walker DI, McComb AJ (1992) Seagrass degradation in Australian coastal waters. Mar Poll Bull 25:191-195

Walker DI, Hillman KA, Kendrick GA, Lavery P (2001) Ecological significance of seagrass: Assessment for management of environmental impact in Western Australia. Ecol Eng 16:323-330

Ward LG, Kemp WM, Boynton WR (1984) The influence of water depth and submerged vascular plants on suspended particulates in a shallow estuarine embayment. Mar Geol 59:85-103

White JR, Roman MR (1992) Egg production by the calanoid copepod Acartia tonsa in the mesohaline Chesapeake Bay: the importance of food resources and temperature. Mar Ecol Prog Ser 86:239-249

Willard DA, Cronin TM, Verado S (2003) Late-Holocene climate and ecosystem history from Chesapeake Bay sediment cores, USA. Holocene 13:201-214

Yamamoto T (2003) The Seto Inland Sea-eutrophic or oligotrophic? Mar Poll Bull 47:37-42

Zhang J, Jørgensen SE, Beklioglu M, Ince O (2003) Hysteresis in vegetation shift-Lake Morgan prognoses. Ecol Model 164:227-238

Zimmerman AR, Canuel EA (2000) A geochemical record of eutrophication and anoxia in Chesapeake Bay sediments: anthropogenic influence on organic matter composition. Mar Chem 69:117-137

Zimmerman AR, Canuel EA (2002) Sediment geochemical records of eutrophication in the mesohaline Chesapeake Bay. Limnol Oceanogr 47:1084-1093

Submitted: December 21, 2004; Accepted: August 21, 2005

Proofs received from author(s): October 25, 2005 